\title{
DESCOLONIZAÇÃO AFRICANA E A CRÍTICA DO DUALISMO ANTROPOLÓGICO EUROPEU: QUANDO O OUTRO DA MODERNIDADE REFLEXIVIZA, CORRIGE E EDUCA A MODERNIDADE
}

\author{
AFRICAN DECOLONIZATION AND THE CRITICISM TO THE EUROPEAN ANTHROPOLOGICAL \\ DUALISM: WHEN THE OTHER OF MODERNITY PONDERS, CORRECTS AND EDUCATES THE \\ MODERNITY
}

\author{
Fernando Danner* \\ Universidade Federal de Rondônia, Brasil \\ Julie Dorrico** \\ Pontifícia Universidade Católica do Rio Grande do Sul, Brasil \\ Leno Francisco Danner*** \\ Universidade Federal de Rondônia, BRasils
}

REsumo: O texto discute a crítica realizada pela descolonização africana relativamente ao dualismo antropológico europeu que serve como substrato para a constituição do discurso filosófico-sociológico-antropológico da modernidade-modernização ocidental e que implica (a) na cisão, na separação, na autonomia, na independência, da endogenia, na autorreferencialidade, na autossubsistência, na autossuficiência e na sobreposição da Europa em relação a todos os outros da Europa, correlatamente (b) à legitimação da Europa, por meio da racionalização, como presente efetivo, atualidade substantiva e abertura e direcionamento ao futuro, a única instância paradigmático-normativa capaz de fundar, legitimar e realizar o universalismo nãoetnocêntrico e não-egocêntrico e com condições de gerar crítica, reflexividade, mobilidade e emancipação, ao contrário de todos os outros da modernidade que, enquanto sopa indiferenciada e generalização absoluta demarcadas por uma condição mítica, são concebidos como perspectiva pré-moderna e antimoderna e, nesse sentido, como passado antropológico, incapazes de gerar crítica, reflexividade, mobilidade e transformação ao longo do tempo, sendo demarcados por dogmatismo-fundamentalismo
ABSTRACT: The paper discusses the criticism performed by African decolonization regarding European anthropological dualism that serves as basis to the constitution of the philosophicalsociological-anthropological discourse of Western modernity-modernization, which implies (a) in the split, separation, autonomy, independence, endogeny, self-referentiality, self-subsistence, self-sufficiency and superposition of Europe in relation over all others of Europe, correlatively to (b) the legitimation of Europe, by means of rationalization, as effective present, substantive actuality and orientation to the future, the only paradigmatic-normative instance which is capable of ground, legitimize and implement the non-ethnocentric and non-egocentric universalism and with condition to generate criticism, reflexivity, mobility and emancipation, contrarily to all others of modernity who, as undifferentiated soup and absolute generalization demarcated by a mythic condition, are conceived as pre-modern and anti-modern perspective and, in this sense, as anthropological past, unable to generate criticism, reflexivity, mobility and transformation along the time, being charaterized for dogmatism-fundamentalism

* Doutor em filosofia pela PUCRS. Professor do Departamento de Filosofia, do Programa de PósGraduação em Filosofia (PPGFIL) e do Mestrado Profissional Interdisciplinar em Direitos Humanos e Desenvolvimento da Justiça (DHJUS) da Universidade Federal de Rondônia UNIR.fernando.danner@gmail.com.** Doutoranda em Teoria da Literatura pelo Programa de Pós-Graduação em Letras da Pontifícia Universidade Católica do Rio Grande do Sul (PUCRS). Email: juliedorrico@gmail.com.*** Doutor em Filosofia pela Pontifícia Universidade Católica do Rio Grande do Sul (PUC RS). Professor de teoria política contemporânea no Departamento de Filosofia e no Programa de Pós-Graduação em Filosofia da Universidade Federal de Rondônia. E-mail:leno_danner@yahoo.com.br 
e contextualismo-particularismo. descolonização africana, por meio da tríade eurocentrismo-colonialismo-racismo e/como fascismo, desconstruirá o dualismo antropológico, a cegueira histórico-sociológica e a romantização normativo-filosófica do racionalismo ocidental e, a partir da voz-práxis dos sujeitos menorizados-colonizados construídos pela Europa em termos do racismo estrutural, apresentará uma nova perspectiva de um universalismo não-etnocêntrico e nãoegocêntrico que somente pode ser gerado e sustentado como descolonização, isto é, como superação do dualismo antropológico e do consequente maniqueísmo politico-moral que, enquanto racismo estrutural, tem demarcado a relação assimétrica da Europa para com os povos não-europeus sob a forma de usurpação, instrumentalização, produção de minorias político-culturais e, como coroamento disso, de realização de etnocídios-genocídios contra negros e indígenas.

Palavras-Chave: Modernidade Europeia; Outro da Modernidade; Dualismo Antropológico; Eurocentrismo-ColonialismoRacismo; Crítica da Modernidade.
A and contextualism-particularism. African decolonization, by means of the triad eurocentrism-colonialism-racism as fascism, will deconstruct the anthropological dualism, the historical-sociologica blindness and the normative-philosophical romanticization of Western rationalism and, from the voice-praxis of the minorized-colonized subjects constructed by Europe in terms of structural racism, will furnish a new perspective of a non-ethnocentric and non-egocentric universalism which can be generated and sustained only as decolonization, that is, as overcoming of the anthropological dualism and of the consequent political-moral dualism that, as structural racism, have streamlined the asymmetric relationship of Europe to non-European peoples in terms of usurpation, instrumentalization, construction of political-cultural minorities and, as the crowning point of all these, realization of etnocides-genocides against Black and Indigenous peoples.

KEYWORDS: European Modernity; Other of Modernity; Anthropological Dualism; Eurocentrism-Colonialism-Racism; Criticism of Modernity

\section{CONSIDERAÇÕES INICIAIS}

Neste artigo, desenvolveremos uma crítica ao discurso filosófico-sociológico-antropológico da modernidade-modernização ocidental ou europeia, tal como ele é tematizado, por exemplo, em autores como Max Weber, Jürgen Habermas e Axel Honneth. Nosso foco de crítica diz respeito à utilização, por estes autores (e de um modo mais geral, por parte da filosofia europeia uniformemente), de um dualismo antropológico enquanto eixo estruturante seja de sua compreensão da especificidade da Europa em relação a todos os outros da Europa, seja da fundação de uma noção de universalismo epistemológicomoral pós-tradicional que serviria tanto para a crítica da modernidade desde si mesma e por si mesma quanto para o enquadramento de todos os outros da modernidade por parte da própria modernidade. Esse dualismo antropológico parte da separação, da independência, da autonomia, da endogenia, da autorreferencialidade, da autossubsistência e da sobreposição da Europa como singularidade em termos de correlação de racionalização e universalismo pós-tradicional versus todos os outros da modernidade como generalidade e indiferenciação antropológica na correlação de mito-tradicionalismo e contextualismo-particularismo. Nesse sentido, pelo dualismo antropológico, a Europa pode se conceber, se explicar e se justificar apenas por princípios e dinâmicas internos, no caso a racionalização sociocultural, sem qualquer menção aos outros da modernidade e, de modo específico, invisibilizando, silenciando e apagando a tríade eurocentrismo-colonialismo-racismo e/como fascismo de sua autocompreensão normativa como universalismo pós-tradicional via racionalização, da história da modernidade-modernização ocidental. Como consequência, a Europa é presente efetivo, atualidade substantiva e abertura e direcionamento ao futuro por suas próprias condições socioculturais internas, ao passo que os outros da modernidade, dada sua constituição societal-cultural-cognitiva mítica e/ou tradicionalista, são passado antropológico também por suas próprias condições internas: a Europa, por meio da racionalização, é capaz de crítica, reflexividade, mobilidade e transformação ao longo do tempo, ao passo que os outros da modernidade, por causa de sua condição mítica, não são racionais, não geram racionalização social, permanecendo acríticos, irreflexivos, ossificados, imobilizados e travados nesse mesmo passado antropológico; a Europa, assim, é e gera transformação e emancipação sociopolíticas, ao 
passo que os outros da modernidade mantêm-se travados em termos de dogmatismo e fundamentalismo.

Nossa crítica ao dualismo antropológico europeu se dará a partir da descolonização africana enquanto uma voz-práxis anticolonial, antifascista, antitotalitária, antirracista e não-fundamentalista que tem exatamente na reconstrução da modernidade-modernização ocidental por parte dos grupos-sujeitos colonizados-racializados sua dinâmica estruturante, e que afirma a tríade eurocentrismo-colonialismoracismo e/como fascismo enquanto a chave epistêmico-política de interpretação, de enquadramento e de reflexivização da modernidade-modernização ocidental, bem como, antes de tudo, de justificação e de realização da própria luta anticolonial. Nessa crítica ao dualismo antropológico europeu, a descolonização africana insistirá que o negro e o índio genéricos são construções da Europa a partir de sua expansão universalizante sob a forma de usurpação, instrumentalização, produção de menoridades político-culturais e de cometimento de processos de etnocídio-genocídio planificados, ou seja, de que o branco-branquitude-Europa, o negro-negritude-África e o índio-indianidade-América (ou mesmo o oriental-orientalidade-Oriente genérico) são construções que emergem através da tríade eurocentrismocolonialismo-racismo e/como fascismo. Nesse sentido, não haveria dualismo antropológico e, nesse caso, é ilusória e mistificada essa separação, essa endogenia, essa autonomia e essa internalidade da Europa como singularidade em termos de correlação de racionalização e universalismo versus todos os outros da Europa como generalidade indiferenciada na intersecção de mito-tradicionalismo e contextualismo-dogmatismo, assim como é ilusória, mistificada e falsa a justificativa de que Europa, de um lado, e todos os outros da Europa, de outro, representam realidades antropológicas diferenciadas (Europa, racionalização, universalismo, presente efetivo e abertura ao futuro, critica, reflexividade, mobilidade e emancipação; todos os outros da modernidade, mito, contextualismo-particularismo, passado antropológico, dogmatismo, fundamentalismo, imobilidade, travamento, ossificação) por causa de princípios internos. O negro e o índio são construções europeias, a Europa se constrói por meio da negativação, da menorização, da instrumentalização, da usurpação e do assassinato planificado dos outros da modernidade; o atraso, a imobilização e o travamento dos outros da modernidade no passado antropológico e a condição da Europa como presente substantivo e abertura ao futuro se devem ao eurocentrismo-colonialismo-racismo e/como fascismo, muito mais do que a princípios internos e endógenos e a processos autorreferenciais próprios a cada uma dessas realidades antropológicas. Desse modo, o dualismo antropológico assumido pelas teorias da modernidade europeias contemporâneas como base da constituição de seu discurso filosófico-sociológico-antropológico da modernidademodernização ocidental não é uma mera premissa antropológica, um mero recurso epistemológico neutro que explicita uma realidade factual à Europa, de um lado, e a todos os outros da Europa, de outro; ele é um constructo político-normativo caudatário da tríade eurocentrismo-colonialismo-racismo e/como fascismo, e sua utilização contemporânea reforça (a) a deslegitimação e a exclusão dos outros da modernidade como parte e interlocutores do processo de modernidade-modernização ocidental; (b) o apagamento, a invisiblização e o silenciamento acerca do eurocentrismo-colonialismo-racismo e/como fascismo; e (c) a possibilidade de uma crítica e de uma reconstrução da modernidade desde a descolonização africana e o pensamento indígena brasileiro, ou seja, desde uma voz-práxis anticolonial, antifascista, antitotalitária, antirracista e não-fundamentalista que tenha condições de superar esse mesmo dualismo antropológico. Por isso, a descolonização africana se assumirá como poder originário da diferença enquanto positividade, descentração epistêmico-política e pluralização discursiva relativamente ao humano de um modo geral e ao processo de modernidade-modernização ocidental em particular.

\section{O DUALISMO ANTROPOLÓGICO COMO BASE DAS TEORIAS DA MODERNIDADE EUROPEIAS}

As teorias da modernidade europeias, para o nosso caso aqui as posições de Max Weber, Jürgen Habermas e Axel Honneth, objetivam a realização de um triplo objetivo epistemológico-político, especialmente as duas últimas, que são eminentemente normativas, a saber: (a) reconstruir teoricamente a emergência, a constituição e o desenvolvimento da modernidade-modernização europeia como estrutura societal-cultural-cognitiva pós-tradicional por meio da racionalização, buscando seus fatores detonadores, seus princípios dinamizadores e chegando-se ao seu resultado corrente, atual; (b) oferecer, com isso, um conceito normativo-descritivo de modernidade que possa concomitantemente permitir 
análises empíricas sobre as suas potencialidades e os seus problemas (inclusive definindo quais são essas potencialidades e quais são de fato esses problemas) e servir enquanto plataforma crítica, reflexiva e transformadora desses déficits de modernização, o que implicaria também em se incrementar suas potencialidades carentes de efetividade, travadas por algum problema interno; e (c), como sói acontecer com Jürgen Habermas e Axel Honneth, dar um passo além da mera análise da modernidademodernização europeia (recusando, assim, que a Europa seja apenas contextualista ou particularista, apontando-se para sua universalidade), no sentido de estabelecer esse princípio e esse processo constitutivos primariamente da modernidade-modernização europeia como um caminho evolutivo que, na verdade, faz parte do gênero humano como um todo e de cada sociedade-cultura em particular, ainda que em um estágio menos desenvolvido relativamente àquele da sociedade-cultura-consciência europeia. Nesse caso, a teoria da modernidade é, de modo mais amplo, uma teoria da constituição, do desenvolvimento e do caminho historial do gênero humano enquanto sociedade-cultura-consciência póstradicional, realizada e alcançada pela primeira vez pela Europa, a qual serve como parâmetro para a explicitação, o enquadramento, a definição e o escalonamento do passado evolutivo humano e, no mesmo diapasão, para a reflexão sobre suas condições presentes e para sua formulação de rotas evolutivas direcionadas ao futuro. Ora, da constituição de um discurso filosófico-sociológicoantropológico da modernidade-modernização europeia por si mesma e desde si mesma à sua associação direta seja com a condição presente ou atual e o direcionamento futuro do gênero humano como um todo, seja com a capacidade de desvelamento do passado evolutivo humano e do consequente escalonamento das sociedades, das culturas e dos povos em uma cadeia evolutiva estratificada e hierarquicamente definida, temos um grande conjunto de raciocínios e de afirmações que não são fáceis de digerir e que, na verdade, escondem uma condição nada agradável assumida e defendida por essas mesmas teorias da modernidade, a saber, a deslegitimação dos outros da Europa, isto é, dos outros da modernidade, sua invisibilização, seu silenciamento e sua exclusão desse mesmo discurso filosóficosociológico-antropológico da modernidade que se pretende exatamente universalista em termos póstradicionais, com caráter não-etnocêntrico e não-egocêntrico (e, portanto, que se afirma anticolonial, antirracista e antifascista) e, finalmente, o apagamento da tríade eurocentrismo-colonialismo-racismo e/ como fascismo enquanto um dos eixos estruturantes não só da constituição da autocompreensão de mundo europeia, mas também de sua expansão universal em termos de uma lógica da reificação humana, da usurpação territorial e simbólica, da produção de menoridades político-culturais racializadas e, então, de realização de processos amplos de etnocídio-genocídio contra povos não-europeus.

Dito de outro modo, as teorias da modernidade europeias - mormente as três que citamos acima - assumem como seu ponto de partida e como sua base de constituição um dualismo antropológico que tem como consequências (a) a completa separação, independência, autonomia, endogenia, autorreferencialidade, autossuficiência, autossubsistência e sobreposição da modernidade europeia em relação aos outros da modernidade, de modo que a modernização passa a ser concebida como um processo basicamente interno, um esforço da Europa por si mesma, desde dentro de si mesma e por seus próprios princípios, em termos de superação de sua menoridade como tradicionalismo e de consecução de sua maioridade como perspectiva pós-tradicional via racionalização; (b) a contraposição radical e a diferenciação forte entre a modernidade mais uma vez como racionalização, que leva à desnaturalização, à historicização e à politização da sociedade, da cultura e da consciência, e os outros da modernidade como tradicionalismo em geral, fundados em uma condição mítica que naturaliza e, assim, despolitiza a sociedade, a cultura e a consciência, colocando-as em uma condição a-histórica que imobiliza e subsume seus processos de socialização e de subjetivação em uma cadeia de ferro dourada em termos mágicoanimistas, a qual não pode ser rompida; (c) por meio da afirmação da racionalização enquanto eixo estruturante apenas da Europa, como seu princípio ontogenético mais básico e exclusivo, a pressuposição de que somente a modernidade-modernização ocidental é racional e gera racionalização social, de modo a constituir-se enquanto presente efetivo, atualidade substantiva e abertura ao futuro, inclusive a partir da ideia de que somente a racionalização sociocultural e uma perspectiva normativa pós-tradicional têm condições de, em gerando diferenciação social, dialética política aguda, práxis histórica e individualização forte, viabilizar autoconsciência, autocorreção e autocontrole, ou seja, crítica, reflexividade, mobilidade e emancipação ao longo do tempo, situação que não seria detonada pelos outros da modernidade, posto sua sociedade-cultura-consciência tradicional ou mítica não ser racional e não gerar racionalização social, ficando enredada em bases essencialistas e naturalizadas com caráter pré-político, pré-cultural e a-histórico, o que implicaria em que os outros da modernidade como 
tradicionalismo em geral são passado evolutivo humano, inferiores à modernidade-modernização europeia como racionalização e como condição normativa pós-tradicional - os outros da modernidade não apenas não seriam capazes de autoconsciência, autorreflexividade e autotransformação ao longo do tempo, como também não teriam condições nem de estabelecer uma crítica à modernidademodernização europeia desde fora (porque são passado evolutivo como tradicionalismo-concretismo) e nem de fundar uma noção intersubjetivamente vinculante de universalismo epistemológico-moral (porque são contextualistas e particularistas, ao contrário da modernidade, que é universalista) que, mais uma vez, somente são possiveis em termos de racionalização sociocultural europeia; e (d) tanto a deslegitimação dos outros da modernidade enquanto formas de ser e estar no mundo pujantes e como perspectivas normativo-paradigmáticas de crítica, de enquadramento, de interpretação e de reorientação da modernidade ocidental (e em primeiro lugar de si mesmos como singularidades antropológicas) quanto o apagamento, o silenciamento e a invisibilização da tríade eurocentrismo-colonialismo-racismo e/como fascismo enquanto eixo estruturante da expansão universal da Europa e, nesse caso, de sua reificação, de sua usurpação, de sua menorização e, ao fim e ao cabo, de seu processo de etnocídiogenocídio contra povos não-europeus, como dizíamos acima.

Nesse sentido, as teorias da modernidade-modernização europeia contemporâneas assumem e continuam por outros meios - e certamente não de modo inconsciente - a herança colonial em termos de racismo estrutural e de eurocentrismo cultural-histórico, que foram, como argumentaremos ao longo do texto, as duas bases legitimadoras da expansão colonial, da usurpação simbólico-territorial e do etnocídio-genocídio contra povos não-europeus concomitantemente - mas sem causar nenhuma convulsão mais aguda e nenhum dano na consciência moral racionalizada e universalista e nas formulações de direitos do homem e do cidadão, em que todos nasceriam iguais e com os mesmos direitos e onde as desigualdades somente seriam justificadas pelo bem comum - ao próprio desenvolvimento do Iluminismo europeu e da luta contra o modelo antropológico-político do Antigo Regime. Nesse sentido, o dualismo antropológico assumido por teorias da modernidade contemporâneas é efetivamente uma continuação por outros meios, em geral mais soft e menos escancarada do que nos seus autores europeus dos séculos XVII-XIX, da dualidade entre razão ou mente e corpo ou instinto, entre cultura e natureza, entre civilização e barbárie, entre estado civil e estado de natureza etc., distinções que colocariam os povos não-europeus, em especial os negros e os indígenas, como mero corpo, instinto, natureza, barbárie, estado de natureza etc. Essa dualidade construida em termos de filosofia moderna se ramificou em - e, na verdade, foi correlacionada com - uma filosofia da história unilinear que partiria de um Oriente genérico, passaria por Grécia e Roma, pelo Medievo (nesse caso, pelo Cristianismo e pela cultura-religião-filosofia árabe) e chegaria, então, à Europa ocidental, ao processo de formação dos Estados-nação, da secularização cultural, da revolução política, da centralidade da razão científica e da afirmação dos Estados de direito e dos direitos do homem e do cidadão etc. - uma filosofia da história que conceberia o processo de evolução do gênero humano como um grande caminho de modernização que tem na Europa seu ápice, seu apogeu, sua condição presente e, com isso, também seu artífice principal em termos de planejamento e de orientação ao futuro (G. W. F. Hegel é o principal autor dessa posição); e uma noção de evolucionismo biológico que, por meio da seleção sexual, permite comprovar a unidade do gênero humano (todas as raças humanas provêm de um ancestral símio comum), mas também sua bifurcação e sua diferenciação ao longo do tempo, com a associação direta de brancura e/como Europa, negritude e/como África e indianidade e/como América, inclusive explicando-se o porquê da superioridade civilizacional, cultural e intelectual do branco europeu em relação ao negro africano e ao índio americano, a qual é caudatária da seleção sexual pujante no primeiro (monogamia e eugenia social sob a forma de seletividade nos casamentos entre os gruposindivíduos) e da seleção sexual deficitária nos outros (poligamia, infanticídio e escravização da mulher são, para Charles Darwin, a explicação para o atraso evolutivo dos negros africanos e dos índios americanos). Nesse sentido, se com Hegel temos a contraposição entre história (Europa) e ausência de história (povos negros e indígenas), entre racionalidade, autoconsciência, estado civil e universalidade (Europa) versus mitologia, heteronomia, estado de natureza e selvageria (os outros da modernidade), em Darwin temos o dualismo povos civilizados (brancos europeus) versus povos semisselvagens ou animalizados (os povos negros e indígenas). Como dissemos, o dualismo antropológico próprio à filosofia e à biologia modernas, na correlação de história etnocêntrica e de racismo biológico, é prosseguido nas teorias da modernidade contemporâneas, ainda que por outros meios, obviamente, mas levando a uma mesma consequência, a defesa de um purismo, de um exclusivismo e de uma endogenia 
absolutos da Europa em relação a todas as outras sociedades-culturas humanas, a colocação de todas essas sociedades-culturas humanas em uma sopa indiferenciada e insossa como tradicionalismo em geral, a deslegitimação dos outros da modernidade como passado antropológico e, finalmente, como fecho de abóboda de tudo isso, o apagamento, o silenciamento e a invisibilização da tríade eurocentrismo-colonialismo-racismo e/como fascismo enquanto eixo estruturante tanto da constituição da modernidade europeia quanto, como condição para isso, de sua expansão universal em termos de reificação, usurpação e etnocídio-genocídio planificados - nesse sentido, inclusive, na medida em que a Europa, por meio desse dualismo, condena os povos não-europeus ao passado antropológico, como déficit de modernização e/porque déficit de racionalização, ela se assume como presente efetivo, atualidade substantiva e direcionamento ao futuro e, então, como o juiz, o árbitro e o guia da evolução do gênero humano como um todo e de cada sociedade-cultura em particular, tornando-se a instância universal de definição de quem entra e de quem não entra, e de como e de quando entra ou não, na rota da modernidade-modernização ocidental. Com o dualismo antropológico, o exclusivismo e a endogenia europeus como universalismo pós-tradicional via racionalização representam a invisibilização e a deslegitimação dos outros da modernidade como mero contextualismo-particularismo fundamentalista; o presente efetivo e o direcionamento ao futuro enquanto politização, autoconsciência e liberdade representam a imobilização e o engessamento dos outros da modernidade no passado, como mera submissão ao meio mágico-animista, ambos levando ao eurocentrismo epistêmico-político e à monopolização discursiva não apenas em torno à definição da modernidade-modernização ocidental, mas também em torno ao próprio sentido do humano, à própria compreensão e orientação do nãomoderno; a partir de agora, com esse dualismo antropológico euronorcêntrico, qualquer objetividade possível tem de passar pelo crivo da modernidade ou, na verdade, tem de ser construída por ela, desde sua base paradigmática e seus sujeitos epistemológico-politicos. Com efeito, Max Weber começa sua delimitação de um discurso filosófico-sociológico-antropológico da modernidade-modernização europeia por si mesma e desde si mesma exatamente com a afirmação da singularidade, da endogenia e da independência absolutas da Europa como racionalização e, então, como universalismo histórico em relação a todas as outras sociedades-culturas como tradicionalismo em geral. Ele diz:

O filho da moderna civilização ocidental, que trata de problemas histórico-universais, o faz de modo inevitável e lógico a partir da seguinte dinâmica: que encadeamento de circunstâncias possibilitou que aparecessem no Ocidente, e somente no Ocidente, fenômenos culturais (pelo menos como os representamos a nós) que apresentam uma direção evolutiva de alcance e de validade universais? (WEBER, 1984, p. 11; os destaques são nossos) ${ }^{1}$.

Note-se, na passagem acima, aquela que, como estamos argumentando, é a tônica e a orientação fundacionais das autocompreensões normativas da modernidade-modernização europeia, ou seja, o dualismo entre a Europa e todos os outros da Europa que significa, ao mesmo tempo, (a) esse sentido exclusivista, endógeno, purista, autônomo, independente, separado, autossubsistente, autossuficiente e autorreferencial da modernidade-modernização ocidental por si mesma, desde si mesma e a partir de princípios e de dinâmicas basicamente seus e, na verdade, completamente internos - a racionalização social em termos de secularização das imagens metafísico-teológicas de mundo e a constituição consequente de um universalismo histórico que, mais uma vez, como se pode perceber na passagem acima, são próprios apenas e tão somente à Europa, são gerados apenas e tão somente por ela; e, assim, (b) a assimetria entre essa singularidade aguda da Europa e a constituição de uma visão genérica (caudatárias das ideias racializadas e etnocêntricas do negro genérico e do índio genérico) do outro da modernidade como sopa insossa, bloco informe e fusão indistinta como tradicionalismo em geral. Notese, ademais, e esta seria uma terceira característica desse dualismo antropológico, a perspectiva ainda sub-reptícia da pressuposição de que o universalismo histórico (e a consequente correlação umbilical de modernidade-modernização europeia, racionalização social e universalismo histórico) é a condição efetivamente geradora de atualidade substantiva, de presente efetivo e de abertura ao futuro, ou seja, como a condição hodierna do gênero humano enquanto modernização ou europeização, o que colocaria a Europa exatamente em um novo e ainda original estado civilizacional-paradigmático-consciencial que não foi alcançado por nenhuma outra civilização, por nenhum outro povo, por nenhuma outra cultura e que, na verdade, só pode ser alcançado em termos de modernização europeia, racionalização sociocultural e universalismo histórico. Note-se, finalmente, a consolidação do dualismo antropológico entre o nós, europeus como modernização, racionalização e universalismo histórico, versus todos os outros da Europa como mito ou tradicionalismo, perspectiva mágico-animista e, então, contextualismo- 
concretismo: esse dualismo de antemão atribui uma independência, uma endogenia e uma internalidade absolutas da Europa, obviamente superior aos outros da modernidade por causa da racionalização, ao mesmo tempo em que coloca estes, como dissemos acima, em uma generalização que simplesmente apaga suas singularidades e nega sua relacionalidade para com a modernidade (e desta para com aqueles), como se todos os outros da modernidade fossem uma e a mesma coisa, a saber, tradicionalismo em geral enquanto condição pré-moderna e antimoderna. Ora, é exatamente dessas quatro premissas que Jürgen Habermas parte com o objetivo, primeiramente, de construir um discurso filosóficosociológico-antropológico da modernidade-modernização europeia, no sentido de diagnosticar suas especificidades internas, suas potencialidades e seus problemas, inclusive seus princípios estruturantes, e, depois, em segundo lugar, de assumi-la como uma perspectiva de universalismo pós-tradicional via racionalização cultural-comunicativa enquanto o verdadeiro sentido e a condição presente-atual da evolução da Europa moderna rumo às sociedades do capitalismo tardio (nesse caso, Europa ocidental e, agora, América do Norte - o popular Primeiro Mundo da Guerra Fria) (cf.: HABERMAS, 2012a, p. 588590; HABERMAS, 2012b, p. 689-690). Com efeito, para Habermas, se quisermos saber o que a Europa é enquanto sociedade-cultura-consciência racionalizada, enquanto universalismo pós-tradicional, devemos saber o que os outros da modernidade não são enquanto sociedade-cultura-consciência e, nesse sentido, a comparação e a deslegitimação dos outros da modernidade, por meio do dualismo antropológico, consiste mais uma vez no passo estrutural e na escolha fundacional do discurso filosófico-sociológico-antropológico da modernidade-modernização europeia. Habermas diz:

À medida que procuramos aclarar o conceito de racionalidade com base no uso da expressão "racional", tivemos de nos apoiar sobre uma pré-compreensão que se encontra ancorada em posicionamentos modernos da consciência. Até o momento, partimos do pressuposto ingênuo de que na compreensão de mundo moderna expressam-se certas estruturas da consciência que pertencem a um mundo da vida racionalizado e por princípio possibilitam uma condução racional da vida. Implicitamente, relacionamos à nossa compreensão de mundo ocidental uma pretensão de universalidade. Para entender o significado dessa pretensão de universalidade, recomenda-se fazer uma comparação com a compreensão de mundo mítica. Em sociedades arcaicas, os mitos cumprem de maneira exemplar a função unificadora própria às imagens de mundo. Ao mesmo tempo, no âmbito das tradições culturais a que temos acesso, eles proporcionam o maior contraste em relação à compreensão de mundo dominante em sociedades modernas. Imagens de mundo míticas estão muito longe de nos possibilitar orientações racionais para a ação, no sentido que as entendemos. No que diz respeito às condições da condução racional da vida no sentido anteriormente apontado, constituem até mesmo uma contraposição à compreensão de mundo moderna. Portanto, na face do pensamento mítico não teriam de se fazer visiveis os pressupostos do pensamento moderno tematizados até o momento (HABERMAS, 2012a, p. 94-95; os destaques são nossos).

Antes de tudo, é importante frisar-se que a "compreensão de mundo mítica" se refere, no caso de Habermas em Teoria do agir comunicativo, aos estudos antropológicos de fins do século XIX e início do século XX, realizados, por exemplo, por Bronislaw Malinowski (Os argonautas do Pacífico ocidental), Edward Evans Evans-Pritchard (Bruxaria, oráculos e magia entre os Azande) e Alfred Reginald Radcliffe-Brown (Estrutura e função na sociedade primitiva) - nesse caso, portanto, trata-se do estudo de sociedades-culturas-povos negros e indígenas, os quais servem como exemplo e substrato seja para essa contraposição com o pensamento moderno em termos de autoafirmação e de autocomprovação deste em relação à sua própria pressuposição de singularidade e de superioridade, com a correlata deslegitimação daqueles, seja, como consequência, para a prova tanto de que a modernidade é totalmente original e superior cultural e normativamente àqueles (no sentido da correlação de racionalização cultural-comunicativa e universalismo pós-tradicional), quanto, por conseguinte, de que aqueles são inferiores cultural e normativamente a ela (no sentido da correlação de mito, naturalizaçãodespolitização e concretismo-dogmatismo-fundamentalismo). Importante salientar, ademais, que Habermas não está dizendo que a capacidade cognitiva de negros e de indígenas é inferior à capacidade intelectual dos brancos europeus, mas está querendo dizer que, sim, a estrutura societal-cultural de negros e de indígenas é inferior à estrutura societal-cultural dos povos europeus, entendendo-se por inferioridade exatamente o potencial de racionalização gerado ou não pelos povos não-modernos comparativamente - e de modo sempre contraposto, é claro - ao potencial de racionalização gerado, detonado e sustentado pela modernidade-modernização europeia (cf.: HABERMAS, 2012a, p. 95-96). 
No caso de Habermas, a distinção epistemológico-antropológica entre a modernidade europeia e os outros da modernidade, feita e utilizada por Max Weber, é complementada e radicalizada com uma distinção de grau evolutivo em termos sociais, culturais e cognitivos entre o sujeito moderno e o sujeito não-moderno, entre a sociedade-cultura moderna e as sociedades-culturas não-modernas. Explicaremos isso logo adiante. Por ora, retornando à passagem acima, pudemos perceber exatamente a pressuposição, inauguradora do discurso filosófico-sociológico-antropológico da modernidade, de que a Europa $e ́$ universal por meio da racionalização e, nesse sentido, de que sua estrutura societal-cultural é racional e gera e fomenta posturas cognitivo-morais racionalizadas, ao passo que as sociedades-culturas míticas não são racionais e não geram e nem fomentam posturas cognitivo-morais racionalizadas - ou seja, de que a Europa é racional e os outros da Europa não o são. Por isso, para Habermas, os outros da Europa representam uma contraposição direta a ela, de modo que seu estudo, seu desvelamento possibilita que se comprove não só a diferença entre a Europa e esses outros da Europa, mas também sua (da Europa) superioridade em termos da correlação de modernização, racionalização e universalismo pós-tradicional, concomitante à correlação do outro da modernidade, mito, tradicionalismo e contextualismo em geral. Nesse sentido, a comparação entre instâncias sociais, culturais e antropológicas tão diferentes quanto a modernidade e o outro da modernidade nos dá uma primeira visão do que os outros da modernidade não são e do que a modernidade é, do que os outros da modernidade são e do que a modernidade não é:

O mais espantoso para nós é o peculiar nivelamento dos diversos campos da realidade: natureza e cultura são projetadas sobre um mesmo plano. Da assimilação recíproca da natureza pela cultura e, ao contrário, da cultura pela natureza surge, por um lado, uma natureza dotada de traços antropomórficos, integrada à rede comunicativa dos sujeitos sociais - uma natureza humanizada, nesse sentido -, e, por outro lado, uma cultura que, naturalizada e reificada, acaba como que sendo absorvida pelo contexto objetivo da interação de poderes anônimos (HABERMAS, 2012a, p. 100-101).

O que os outros da modernidade são enquanto estrutura societal-cultural-cognitiva "tradicional" ou "mítica"? São antropomorfização da natureza e naturalização da sociedade. Isso revela, por um lado, que as sociedades-culturas não-europeias sofrem (e aqui estaria a resposta para seu atraso e seu imobilismo) de um profundo déficit de diferenciação entre as diversas esferas constitutivas da sociedade - no caso de Habermas, epistemológico-cognitivas, político-morais e estético-expressivas; no caso de Honneth, moral, direito e política; por outro lado, que elas são dinamizadas por uma forte despolitização e por uma perspectiva eminentemente a-histórica e naturalizada em termos de compreensão da sociedade, de suas instituições, de seus sujeitos, de seus valores, de seus símbolos e de suas interrelações recíprocas. Sociedades míticas não se compreendem como construções político-normativas demarcadas por relacionalidade, intersubjetividade e historicidade, sendo determinadas desde fora, em termos prépolíticos, pré-culturais e a-históricos. Correlacionados, ambos os pontos acima implicam em que sociedade não-europeias ou míticas sejam demarcadas, como quer Habermas, por uma dupla ilusão, caudatária de sua visão de mundo, de sua estrutura societal-cultural:

Segundo a "perspectiva do pensamento ilustrado", o pensamento selvagem gera uma "dupla ilusão": (1) uma ilusão sobre si mesmo: confere à identidade por ele criada uma existência exterior ao ser humano e independente dele, alienando-o de si mesmo em suas próprias imagens de mundo; (2) o pensamento percebe o mundo como possuindo seres imaginários análogos ao ser humano (HABERMAS, 2012a, p. 101).

Nesse sentido, Habermas pode definir a experiência fundamental das sociedades míticas como uma forma de abandono indefeso ao meio e, nesse caso, em termos de uma perspectiva mágico-animista totalizante, massificadora e unidimensional que correlatamente naturaliza, despolitiza e imobiliza ou trava os grupos-sujeitos não-modernos em uma condição de ossificação no passado humano - na medida em que, aliás, para essas sociedades míticas o presente e o futuro são uma mera repetição do passado ancestral a-histórico, mágico - e lhes impede de evoluírem rumo à modernização (esta que é, como veremos adiante, o direcionamento basilar do gênero humano enquanto superação do tradicionalismo pré-moderno e antimoderno e consolidação exatamente desse modelo de modernidade-modernização europeia enquanto protótipo definidor e orientador do desenvolvimento do gênero humano como um todo e de cada sociedade-cultura em particular, o que conferiria centralidade antropológica, epistêmica e política à modernidade-modernização europeia em termos de interpretação, definição e orientação de si e dos outros da modernidade, assim como a legitimidade no que se refere ao planejamento e direcionamento ao futuro evolutivo humano). Sujeitos socializados em culturas míticas, nesse sentido, 
não se veem como sujeitos político-normativos construtores de sua sociedade por meio de sua ação teórico-prática autoconsciente e autônoma, mas como objetos do meio natural e da esfera espiritual, interseccionadas; eles não percebem e não entendem a sociedade como uma construção política, histórica e culturalmente localizada, mas como um dado essencialista e naturalizado determinado prépoliticamente, o qual, portanto, não pode ser reflexivizando, enquadrado e transformado ao longo do tempo. É por isso que eles são subsumidos e objetificados por um meio naturalizado e mágico que não permite qualquer transformação de si por meio da ação humana e que somente pode ser enquadrado pela magia, a qual deve manter as coisas no lugar em que sempre estiveram. Ele diz:

[...] experiência fundamental das sociedades arcaicas: a experiência de um abandono indefeso às contingências de um entorno indominado. Em um estado não desenvolvido das forças produtivas, não há como manter esses riscos sob controle. Surge, assim, a necessidade de se estancar esse mar de contingências, ou seja, de se livrar dele por via interpretativa, ou fática, ou imaginariamente (HABERMAS, 2012a, p. 99-100).

O que Habermas está querendo significar, com isso, é que uma sociedade-cultura não-europeia ou mítica não possui uma consciência histórico-política consistente e consolidada, de modo a (a) ser fundada em perspectivas essencialistas e naturalizadas determinadas pré-politicamente, como é o caso do mito; (b) ser compreendida como uma condição a-histórica imutável no espaço e no tempo históricopolíticos; (c) ser assumida como um dado imóvel e ossificado no passado e como passado; e (d) ser centralizada e monopolizada por uma elite totalizante que, ela e somente ela, tem acesso à verdade prépolítica e a-histórica do mundo e do homem. É por isso que, para Habermas, a primeira consequência fundamental originada e consolidada por essa estrutura societal-cultural-cognitiva mítica ou tradicionalista é exatamente o dogmatismo, o fundamentalismo e o fanatismo, aos quais se soma o contextualismo estrito caudatário de uma postura antropológico-normativa concretista que é incapaz não só de diferenciar os múltiplos campos da realidade, mas de pensar o mundo, a si e aos outros para além da identidade essencialista e naturalizada do grupo étnico-moral-religioso (cf.: HABERMAS, 2012a, p. 99). Para o que nos interessa ressaltar dessa contraposição entre a Europa enquanto singularidade absoluta e original como racionalização e todos os outros da Europa enquanto generalização indiferenciada e sopa completamente amalgamada como mito, temos a ideia de que o dogmatismo ou fundamentalismo ou fanatismo é gerado exatamente pela estrutura societal-cultural-cognitiva mítica ou tradicional, que possui esse caráter essencialista e naturalizado calcado em bases pré-políticas, préculturais e a-históricas. Habermas diz:

[...] imagens de mundo míticas impedem um desacoplamento categorial entre natureza e cultura, e isso não apenas no sentido de um emaranhamento conceitual de mundo social e mundo objetivo, mas também no sentido de uma reificação da imagem de mundo linguística, o que tem por consequência que a imagem de mundo seja preenchida dogmaticamente com determinados conteúdos privados de um posicionamento racional e, com isso, privados de crítica (HABERMAS, 2012a, p. 106).

Note-se, nessa passagem, que as sociedades-culturas míticas ou tradicionais são ausentes de crítica e, assim, dogmáticas ou fundamentalistas porque sua imagem de mundo, na medida em que é naturalizada e despolitizada, assume um ponto de vista a-histórico e pré-político totalizante que imobiliza, trava e ossifica os lugares e as relações sociais, as instituições, as práticas e os valores intersubjetivos - ademais de essa mesma imagem de mundo não possibilitar diferenciação entre natureza ou mundo objetivo, sociedade-cultura e subjetividade. A perspectiva dogmática, nesse sentido, produzida culturalmente enquanto uma condição e uma dinâmica internas à imagem de mundo mítica, impede a desnaturalização, a historicização e a politização radicalizadas da sociedade-cultura-consciência, mantendo-a inerte no espaço e no tempo apolíticos enquanto eterna repetição do mesmo. Com isso, emerge uma segunda consequência importante definidora dos outros da modernidade enquanto perspectiva pré-moderna e antimoderna, a qual consiste exatamente no seu imobilismo, no seu travamento e na sua ossificação no passado antropológico, uma vez que, repetimos, perspectivas míticotradicionais são marcadas pela naturalização, pela a-historicidade e pela despolitização da sociedadecultura-consciência, as quais acabam sendo subsumidas por bases essencialistas e naturalizadas dogmáticas ou fundamentalistas. Habermas nos diz mais uma vez:

Até o momento, discutimos o "fechamento" das imagens de mundo sob dois pontos de vista: primeiro, sob o ponto de vista da diferenciação deficiente que há entre as atitudes fundamentais em face dos mundos objetivo, social e subjetivo; segundo, sob o ponto de vista da 
reflexividade falha dessa imagem de mundo, que não pode ser identificada como imagem de mundo, enquanto produto da tradição cultural. Imagens de mundo míticas não são entendidas pelos envolvidos como sistemas interpretativos atrelados a uma tradição cultural, constituídos por nexos internos de sentido, simbolicamente referidos à realidade, vinculados a pretensões de validade e, portanto, passíveis de crítica e aptos à revisão (HABERMAS, 2012a, p. 109).

Não há crítica, reflexividade e transformação em sociedades-culturas mítico-tradicionais, de modo que elas estão, por essa sua condição naturalizada, a-histórica e despolitizada, simplesmente presas a uma condição pré-política que reproduz o passado inerte e ossificado como norma absoluta e como eterna e permanente repetição, a qual está para além de qualquer politização mínima - inclusive, esse mundo apolítico-despolitizado totalizante, massificado e unidimensional sequer permitiria a emergência e a consolidação da subjetividade reflexiva, para não se falar do próprio fato, já citado em outros momentos desse texto, da ausência de diferenciação entre natureza, cultura e individualidade própria às sociedades míticas ou tradicionais (cf.: HABERMAS, 2012a, p. 107-108). Note-se, assim, duas consequências fundamentais do dualismo antropológico entre a Europa como singularidade, endogenia e internalidade absolutas (correlação de modernização, racionalização e universalismo pós-tradicional) e todos os outros da modernidade como generalização absoluta (mito-tradicionalismo, perspectiva mágicoanimista ou fundamentos essencialistas e naturalizados, dogmatismo-fundamentalismo-contextualismo) que emergem dessa comparação entre ambos que leva a uma elevação da Europa e a uma deslegitimação de todos os outros da Europa. A primeira consequência diz respeito ao fato de que a perspectiva póstradicional via racionalização cultural-comunicativa (que é o que efetivamente significa modernidademodernização) foi gerada pela primeira vez pela Europa. Como diz Habermas, "[...] o nível póstradicional da consciência moral se torna acessivel em uma cultura, e mais precisamente na cultura europeia [...] (HABERMAS, 2012a, p. 355; os destaques são de Habermas). No mesmo diapasão, e ainda como parte dessa primeira consequência, tem-se a correlata afirmação de que somente há crítica, reflexividade e emancipação por meio da modernização europeia enquanto perspectiva pós-tradicional, descentrada, diferenciada, não-etnocêntrica e não-egocêntrica, gerada pela racionalização culturalcomunicativa: "[...] a descentração da compreensão de mundo e a racionalização do mundo da vida são condições necessárias para uma sociedade emancipada" (HABERMAS, 2012a, p. 146). É nesse sentido que a Europa, enquanto sociedade-cultura-consciência racionalizada, se constitui como uma perspectiva epistemológico-moral pós-tradicional capaz de crítica, reflexividade, mobilidade e transformação cada vez mais radicalizadas e de que, ao contrário, todos os outros da modernidade, enquanto sociedadecultura-consciência mítica ou tradicional, não são racionais, não geram racionalização social e, assim, não são capazes de crítica, reflexividade, mobilidade e transformação ao longo do tempo. Daqui devém a segunda consequência fundamental desse dualismo antropológico assumido pelas teorias da modernidade europeias, o qual consiste exatamente na ideia de que a Europa se constitui, por causa desse processo de racionalização sociocultural que leva tanto à diferenciação das esferas constitutivas da sociedade (cognitivo-instrumentais referentemente à natureza; político-morais no que se refere à sociedade; estético-expressivas no que se refere à subjetividade; moral, direito e política; razão culturalcomunicativa e razão instrumental; esferas do reconhecimento da família, do direito e da sociabilidadepolítica etc.) quanto à desnaturalização, à historicização e à politização da sociedade-cultura-consciência, na ideia de que a modernidade é presente substantivo, atualidade efetiva e abertura e direcionamento ao futuro em termos de uma perspectiva autorreflexiva, autocontrolada e autocorretiva, ao passo que os outros da modernidade são passado antropológico, ossificado, imobilizado e travado em uma posição naturalizada, apolítico-despolitizada e a-histórica (cf.: HABERMAS, 2002a, p. 438-482; HABERMAS, 2002b, p. 07-53). Por isso, mais uma vez, a crítica, a reflexividade e a transformação somente são geradas em termos de modernidade-modernização ocidental; e só há plena realização humana caudatária da consecução bem sucedida seja da diferenciação social, seja da desnaturalização, da historicização e da politização da sociedade-cultura-consciência, seja, finalmente, de um processo de formação amplo e bem-sucedido que leva à autonomia da subjetividade - nessa e por essa mesma modernidade-modernização ocidental. Sobre isso, Axel Honneth nos diz:

Por conseguinte, o quadro interpretativo geral de que dependemos descreve o processo de formação moral através do qual se desdobrou o potencial normativo do reconhecimento recíproco ao longo de uma sequência idealizada de lutas. Nas distinções teóricas que puderam ser obtidas das reflexões de Hegel e Mead, uma semelhante construção encontra seu ponto de partida sistemático. De acordo com isso, são as três formas de reconhecimento do amor, do direito e da 
estima que criam primeiramente, tomadas em conjunto, as condições sociais sob as quais os sujeitos humanos podem chegar a uma atitude positiva para com eles mesmos; pois só graças à acumulação gradativa de autoconfiança, autorrespeito e autoestima, como garante sucessivamente a experiência das três formas de reconhecimento, uma pessoa é capaz de se conceber de modo irrestrito como um ser autônomo e individuado e de se identificar com seus objetivos e desejos. Ora, essa tripartição se deve a uma retroprojeção teórica de diferenciações que só puderam ser obtidas em sociedades modernas sobre um estado inicial aceito hipoteticamente; pois em nossa análise vimos que a relação juridica só pôde se desligar do quadro ético da estima social no momento em que é submetida às pretensões de uma moral pósconvencional. Nesse sentido, é natural adotar para a situação inicial do processo de formação a ser descrito uma forma de interação social em que aqueles três padrões de reconhecimento estavam ainda entrelaçados uns nos outros de maneira indistinta; a favor disso pode depor a existência de uma moral arcaica e interna de grupo, no interior da qual os aspectos da assistência não estavam separados completamente nem dos direitos de membro da tribo nem de sua estima social. Por isso, o processo de aprendizado moral, que o quadro interpretativo em vista deve expor como modelo, teve de render duas idealizações inteiramente distintas de uma vez só: provocar uma diferenciação dos diversos padrões de reconhecimento e, ao mesmo tempo, dentro das esferas de interação assim criadas, liberar o respectivo potencial internamente inscrito (HONNETH, 2003, p. 266-267; os destaques são nossos).

O reconhecimento social, no caso de Honneth, ou a crítica, a reflexividade e a emancipação, no caso de Habermas, e a desnaturalização, a historicização e a politização da sociedade-culturaconsciência, agora no caso de ambos, somente é possível por meio da diferenciação normativa gerada e consolidada em termos de sociedades modernas: natureza (res extensa), sociedade-cultura (historicidade e politicidade) e individualidade (res cogitans), ou moral, direito e política, ou família, direito e sociabilidade, ou razão cultural-comunicativa e razão instrumental etc. Essas diferenciações possibilitam seja a instrumentalização da natureza, a desnaturalização, a historicização e a politização da sociedadecultura-consciência e a emergência, a consolidação e o protagonismo da subjetividade reflexiva, seja, então, a interrelação, a complementação e a sobreposição entre direito, politica e moral. E, como consequência, somente por meio delas temos, como quer Honneth, a plena realização humana enquanto um processo formativo que é dinamizado nessas e desde essas esferas específicas que exigem formas complementares, embora também diferenciadas, de posicionamento, de justificação, de argumentação e de ação. Ora, tal processo de diferenciação somente é efetivo pela modernidade-modernização ocidental e em termos de uma moral pós-convencional que supera a perspectiva essencialista e naturalizada, ahistórica e apolítico-despolitizada própria às sociedades arcaicas, as quais são fortemente etnocêntricas, fundamentalistas e imobilizadas no espaço e no tempo históricos. Por isso mesmo, também em Honneth o dualismo antropológico aparece em cheio com forma de justificar essa originalidade, essa singularidade e essa primazia absolutas da modernidade-modernização europeia em relação aos outros da modernidade, de modo a se consolidar tanto a ideia de que somente há crítica, reflexividade, mobilidade e emancipação (ou diferenciação social-normativa) ao longo do tempo na e pela modernidade-modernização quanto a atribuição de uma condição de presente efetivo e de abertura ao futuro dessa mesma modernização, com a consequente classificação de todos os outros da modernidade no passado antropológico, como condição pré-moderna e antimoderna. Assim, só a modernidade, na correlação de racionalização, diferenciação social, desnaturalização, historicização e politização da sociedade-cultura-consciência, seria universal em nível pós-tradicional, não-etnocêntrico e nãoegocêntrico, ou seja, presente substantivo e abertura ao futuro do gênero humano, ao passo que todos os outros da modernidade, por sua moral arcaica ou de grupo, ficariam presos, imobilizados e ossificados no passado evolutivo humano. Desse modo, a história da modernidade-modernização ocidental ou europeia pode ser definida e sintetizada enquanto uma grande odisseia interna e como um esforço basicamente endógeno da Europa por si mesma e desde si mesma em termos de saída de sua menoridade como tradicionalismo e de conquista de sua maioridade como racionalização. Mais uma vez é Habermas quem nos dá essa definição da modernidade-modernização europeia como um processo purista, interno e autorreferencial. Ele diz:

Por um lado, a compreensão de mundo descentrada abre a possibilidade de um tratamento cognitivamente objetivado em face do mundo factual e de um tratamento jurídica e moralmente objetivado em face do mundo das relações interpessoais; por outro lado, oferece a possibilidade de 
um subjetivismo liberado dos imperativos de objetivação, no tratamento de uma natureza das carências individualizadas. A transferência dessa compreensão de mundo do plano da tradição cultural para o plano do agir social pode ser acompanhada por três vias. A primeira via, que o próprio Weber negligenciou de forma clara, é aberta por movimentos sociais inspirados em atitudes de defesa tradicionalistas e noções modernas de justiça, em ideais filosóficos de ciência e arte, e ainda em ideias de cunho burguês e (mais tarde) socialista. A segunda trilha conduz a sistemas de ação culturais especializados na elaboração de componentes diferenciados da tradição cultural. Até o século XVIII, surgem o meio científico organizado segundo várias disciplinas, a doutrina jurídica universitária e um espaço jurídico informal, bem como o meio artístico organizado através do mercado. Diante disso, a Igreja vê diminuída sua competência global em relação ao sistema interpretativo cultural; concorrendo com instâncias mundanas, ela afirma para si, ao lado de suas funções diaconais, uma competência parcial em relação a questões moralpráticas. [...] terceira trilha, o caminho certo e honroso da racionalização: entre os séculos XVI e XVIII chega-se na Europa a uma institucionalização do agir racional-teleológico amplamente efetiva e conformadora das estruturas da sociedade em seu todo (HABERMAS, 2012a, 384-385).

De modo mais sintético, Habermas reduz o processo de modernidade-modernização ocidental ou europeu à dinâmica internalista, endógena e autorreferencial de correlação, separação e tensãocontradição entre modernidade cultural (perspectiva pós-tradicional, desnaturalizada, historicizada e profana da sociedade-cultura-consciência) e modernização econômico-social (Estado burocráticoadministrativo e sua patologia básica, a burocratização; mercado capitalista e sua patologia básica, a monetarização), entre racionalidade cultural-comunicativa e racionalidade instrumental, entre mundo da vida e sistemas sociais (cf.: HABERMAS, 2012a, p. 588-590). Nenhuma palavra sobre a tríade eurocentrismo-colonialismo-racismo e, nesse sentido, daquele dualismo antropológico radicalizado, que se funda na cisão, na independência, na separação e na autorreferencialidade absolutas da Europa em relação a todos os outros da Europa, chegamos agora exatamente a essa perspectiva totalmente endógena, fechada e autossuficiente da modernidade-modernização ocidental, a qual é explicada nas suas especificidades, potencialidades e tensões em termos dessa intersecção entre cultura e civilização material, razão cultural-comunicativa e razão instrumental. Temos, com o dualismo antropológico, a consolidação da cegueira histórico-sociológica relativamente à tríade eurocentrismo-colonialismoracismo (na passagem acima pudemos ver que a história da Europa é determinada apenas por fatores, movimentos e dinâmicas internos) e uma defesa romântica do racionalismo moderno como o único lugar da crítica, da reflexividade, da mobilidade e da emancipação, invisibilizando, apagando e silenciamento sobre essa filosofia da história etnocêntrica e esse racismo biológico que foram produzidos pelo racionalismo ocidental e em termos exatamente desse dualismo antropológico. A conclusão é clara: os outros da modernidade, como sopa indiferenciada e amálgama absoluto enquanto tradicionalismo em geral, não têm lugar, não têm voz e não têm vez nas teorias da modernidade europeia, permanecendo no passado antropológico como condição pré-moderna e antimoderna; no mesmo diapasão, enquanto perspectiva separada, independente, internalista, endógena e autorreferencial relativamente à constituição e ao desenvolvimento como Europa (sempre desde de dentro de si mesma, por si mesma e a partir de seus próprios princípios estruturantes), apaga-se e invisibiliza-se o eurocentrismo-colonialismo-racismo, silenciando-se profundamente sobre ele - a culpa pela pré-modernidade se deve aos fatores internos às culturas negras e indígenas; o mérito da Europa se deve aos fatores internos à sua estrutura societalcultural-cognitiva. Aqui chegados, nos perguntamos: seria possível a uma perspectiva moderna compreender uma visão de mundo pré-moderna ou arcaica? Teria o sujeito moderno, racionalizado, condições de compreender o sujeito pré-moderno ou arcaico, de constituição mítico-tradicional? Se sim, como? A essas perguntas, Max Scheler nos dá uma resposta surpreendente. Ele diz:

Graças ao seu espírito, o ser que chamamos 'homem' pode alargar o ambiente circundante à dimensão do universo e objetivar as 'resistências' [...]. O animal ouve e vê, mas sem saber que ouve e que vê. A psique do animal funciona, vive - mas o animal não é nenhum psicólogo e nenhum fisiólogo! Devemos pensar em estados extáticos muito raros do homem - na hipótese plena, na absorção de certos venenos inebriantes, em certas técnicas de inibição consciente do espírito (ou seja, já com intervenção mental), por exemplo, cultos orgiásticos de toda espécie para, de algum modo, nos transferirmos ao estado normal do animal. O animal também não vive os impulsos derivados das suas tendências como seus, mas como atrações e repulsas dinâmicas, que derivam das próprias coisas do meio. $\mathrm{O}$ homem primitivo, que em certos rasgos se encontra 
ainda perto do animal, não diz 'tenho horror a esta coisa', mas 'a coisa é tabu'. Para a consciência animal, existem apenas as atrações e aversões derivadas das coisas do meio ambiente. O macaco, que de repente salta para aqui e, em seguida, para ali, vive, por assim dizer, em êxtases simplesmente pontuais (fuga patológica das ideias do homem) (SCHELER, 2008, p. 12; os destaques são de Scheler).

Note-se que, no caso de Max Scheler, o homem primitivo tem uma perspectiva concretista de mundo (é isso que, aliás, significa a afirmação por Habermas de que ele é demarcado por uma estrutura societal-cultural-cognitiva mítica que naturaliza os sujeitos, as relações e os valores sociais; e a afirmação de Honneth da moral arcaica como indiferenciação das esferas do reconhecimento na família, no direito e na politica e sua submissão a uma perspectiva altamente etnocêntrica, fundamentalistadogmática e egocêntrica). Enquanto perspectiva concretista, o homem primitivo está próximo aos animais - não por acaso o exemplo sempre corriqueiro, enquanto herança colonial-racista, do macaco. Ora, o que é o animal? E o que é o homem (moderno)? O animal é simplesmente corpo biológico: vejase acima a afirmação de Scheler, de que o animal tem corpo, mas não sabe que tem corpo, seja no sentido fisiológico, seja no sentido psicológico); o animal, assim, é apenas uma ramificação do meio, uma parte do meio, determinado totalmente por ele. O homem (moderno) é singularidade como pessoalidade, identidade própria, autoconsciência. Assim, o homem (moderno) como pessoa ou autoconsciência não apenas é livre do meio, como também pode objetivá-lo, isto é, conceituá-lo sistematicamente e produzi-lo e reproduzi-lo instrumental e simbolicamente. $\mathrm{O}$ animal não sabe que é, o homem (moderno) sabe que é. Assim, como o homem (moderno) pode acessar a "consciência", o "ser" desse homem primitivo que, próximo aos animais, pouco sabe que é (ou não sabe que é em sentido estrito)? A resposta de Max Scheler: o homem moderno pode acessar a mente do homem primitivo por meio... de alucinógenos, drogando-se (drogadição, aqui, levaria a uma perspectiva ao mesmo tempo mágica, concretista e de perda da autoconsciência)! A consciência do homem primitivo é alucinação permanente, ausência de autoconsciência, alteração da percepção da realidade, como podemos perceber nos usuários de alucinógenos! Pois bem, um questionamento mais: haveria algum papel proativo das sociedades-culturas-povos míticos em termos de diálogo com a modernidade? Como sujeito do passado, ele teria alguma função mais ampla frente ao sujeito que é presente substantivo e abertura ao futuro? A estes dois questionamentos, Habermas nos dá, mais uma vez, uma resposta surpreendente, a qual, frisese, é a conclusão final de Teoria do agir comunicativo:

O teste definitivo para uma teoria da racionalidade, por meio do qual a moderna compreensão do mundo tenta se assegurar de sua universalidade, só poderia se realizar se as figuras opacas do pensamento mítico se iluminassem e as manifestações bizarras de culturas estranhas se esclarecessem de tal modo que conseguíssemos entender não somente os processos de aprendizagem que "nos" separam "delas", mas também o que desaprendemos no decorrer de nossos processos de aprendizagem (HABERMAS, 2012b, p. 721; os grifos são de Habermas).

Se Max Scheler afirma que o homem primitivo, muito próximo aos animais por causa de sua perspectiva concretista - e o animal é basicamente, para ele, fisiologia e concretismo, especialmente no que se refere aos animais superiores, como os macacos e os cachorros (os quais são seus exemplos acerca dessa condição de animalidade como mera biologia/corpo enquanto contraposta à condição de humanidade como pessoalidade/autoconsciência em A situação do homem no cosmos) - pode ser entendido pelo homem moderno (este e somente este como pessoalidade e como autoconsciência) por meio da ingestão de alucinógenos, os quais nos dariam uma percepção mínima ou aproximada dessa perspectiva ao mesmo tempo mágica, concretista e biologicista, portanto, se Max Scheler pode nos responder sobre como o homem moderno pode ter uma compreensão mínima do homem primitivo, Habermas, de sua parte, nos oferece uma resposta acerca do sentido e do direcionamento desse mesmo homem primitivo - no seu caso, agora, o pensamento mítico e as "culturas estranhas" - relativamente à modernidade-modernização europeia. Nesse diapasão, há, sim, uma grande função a ser desempenhada pelos outros da modernidade relativamente à autocompreensão normativa da Europa enquanto universalismo pós-tradicional por meio da racionalização, e essa importante função consiste exatamente em modernizar-se para, então, confirmar e comprovar que essa pressuposição assumida pela Europa, de que ela é uma estrutura societal-cultural-cognitiva racional e universal, é exatamente verdadeira, de que, assim, o próprio dualismo antropológico assumido por ela está correto, seja no que se refere à evolução humana que vai do tradicionalismo à Europa, seja, finalmente, no fato de que somente a posição epistemológico-politica moderna é capaz de critica, reflexividade e transformação ao longo do tempo, de 
objetivação da história humana, de ação emancipatória no presente e de planejamento e direcionamento ao futuro. Aos outros da modernidade cabe a grande função de dar razão às razões modernas; aos outros da modernidade cabe, por meio de sua racionalização, por meio de sua modernização, comprovar e solidificar os pré-conceitos assumidos pela Europa enquanto universalidade pós-tradicional por meio da racionalização: se eles se racionalizarem, se eles se modernizarem, então eles não só se tornarão algo similar à Europa, como também legitimarão esse conjunto correlato de pressuposições assumidos pelo discurso filosófico-sociológico-antropológico da modernidade-modernização europeia, a saber: (a) o dualismo antropológico entre a modernidade-modernização europeia como universalismo pós-tradicional via racionalidade cultural-comunicativa e todos os outros da modernidade como tradicionalismo em geral, perspectiva mítico-arcaica e, assim, contextualismo e particularismo normativos; (b) a modernidade-modernização europeia como presente efetivo, atualidade substantiva e abertura e direcionamento ao futuro, e todos os outros da modernidade como passado antropológico; (c) a modernidade-modernização europeia, na correlação de desnaturalização, historicização e politização da sociedade-cultura-consciência, como gerando crítica, reflexividade, mobilidade e transformação ao longo do tempo, ao passo que os outros da modernidade, por sua estrutura mítica e pela sua perspectiva de naturalização, a-historicidade e despolitização, gerariam dogmatismo, fundamentalismo, fanatismo, sendo demarcados pela ausência de crítica, de reflexividade, de mobilidade e de transformação ao longo do tempo; e (d), então, o paradigma normativo moderno como o escalonador e o estratificador universal que confere a cada sociedade-cultura-povo o seu lugar nesse grande processo evolutivo próprio ao gênero humano, como o guarda-chuva normativo que, por seu caráter formalista, não-etnocêntrico e não-egocêntrico, valida ou invalida qualquer perspectiva axiológica particular, como o sujeito-condição protagonista da crítica, da reflexividade e da emancipação (inclusive do diálogo-práxis intercultural), bem como enquanto a ponta de lança relativamente ao futuro do gênero humano, ao passo que o tradicionalismo em geral, como passado ossificado e imobilizado e como ausência de crítica, de reflexividade, de mobilidade e de transformação, não tem condições nem de criticar-se e de reflexivizarse a si mesmo (pois é um paradigma naturalizado, a-histórico e despolitizado), nem de criticar e de reflexivizar a modernidade-modernização europeia (pois é passado evolutivo) e nem, finalmente, de servir de base ao universalismo pós-tradicional (porque o tradicionalismo é etnocêntrico-egocêntrico, particularista-contextualista e fundamentalista-dogmático), os quais ficam centralizados e monopolizados pela própria modernidade-modernização ocidental.

Ora, com isso está encerrado o discurso filosófico-sociológico-antropológico da modernidademodernização europeia em sua perspectiva e em sua dinâmica puristas, endógenas, autorreferenciais, autossuficientes, autossubsistentes e sobrepostas aos outros da modernidade como tradicionalismo em geral? Serão esses argumentos suficientes para provar o fato de que a estrutura societal-culturalcognitiva europeia é realmente universal em termos pós-tradicionais via racionalização culturalcomunicativa? O que nos garante que, afinal de contas, todos os outros da Europa como tradicionalismo em geral são efetivamente - ou, na verdade, potencialmente - capazes de racionalização (Habermas) ou de diferenciação social e luta por reconhecimento (Weber, Habermas e Honneth)? É aqui que emerge o último golpe contra os outros da Europa por parte das teorias da modernidade europeias, e ele consiste na defesa de que, na verdade, tanto a razão/racionalização quanto a diferenciação social-normativa e as lutas por reconhecimento são mais do que mera especificidade da Europa enquanto uma sociedadecultura-consciência totalmente singular na história do gênero humano (não diremos da pluralidade humana, porque só há Europa, de um lado, e todos os outros da Europa do outro - conforme consequência do dualismo antropológico europeu); eles são uma condição ontogeneticamente constitutiva da Europa, sim, e aqui de modo pleno e efetivo, mas também dos outros da Europa de modo ainda incipiente. Ou seja, se primeiramente a racionalidade cultural-comunicativa, a diferenciação social-normativa e as lutas por reconhecimento foram afirmadas por Habermas, por Weber e por Honneth como algo intrínseco, específico e muito particular à Europa ou à modernidade-modernização ocidental ou às sociedades-culturas pós-tradicionais ou pós-convencionais (conceitos que remetem todos ao racionalismo europeu, obviamente), inclusive no sentido de deslegitimar os outros da modernidade como passado evolutivo por não serem racionais e não gerarem racionalização social, agora a razão cultural-comunicativa, a diferenciação social-normativa e as lutas por reconhecimento são, na verdade, uma condição fundacional do próprio gênero humano de um modo geral e de cada sociedade-culturaconsciência em particular, o que, por consequência, transformará o gênero humano em um grande processo de modernidade-modernização ocidental, em um grande processo de europeização que encontra 
nela sua verdade, seu ápice e se apogeu, sua condição verificadora e, finalmente, sua base protagonista e dinamizadora em relação ao futuro (inclusive naquele sentido de servir como critério-sujeito para a estratificação universal do lugar de todos e de cada um nessa grande odisseia do gênero humano como modernização, como europeização). Habermas diz:

Se não delineamos o racionalismo ocidental a partir da perspectiva conceitual da racionalidade propositada e da dominação do mundo e, mais que isso, se tomamos como ponto de partida a racionalização de mundo descentralizada, impõem-se as seguintes perguntas: onde se expressa um acervo formal de estruturas universais da consciência? Não é, afinal, nas esferas de valor culturais desenvolvidas de maneira obstinada sob os parâmetros valorativos abstratos de verdade, correção normativa e autenticidade? O que constitui, afinal, o patrimônio da "comunidade dos homens de cultura", presente como ideia reguladora? Não são as estruturas do pensamento científico, das noções jurídicas e morais pós-tradicionais e da arte autônoma - tal como formadas no âmbito da cultura ocidental? A posição universalista não precisa negar o pluralismo e a incompatibilidade das marcas históricas da "condição cultural própria ao ser humano", mas percebe que essa multiplicidade das formas de vida está restrita aos conteúdos culturais e afirma que toda cultura, se fosse o caso de alcançar um certo grau de "conscientização" ou de "sublimação", teria de compartilhar certas qualidades formais da compreensão de mundo moderna. A assunção universalista refere-se, portanto, a algumas caracteristicas estruturais e necessárias próprias a mundos da vida modernos. Por outro lado, quando tomamos essa concepção universalista como coerciva somente para nós, o relativismo que se refuta no plano teórico acaba retornando no plano metateórico. Não creio que um relativismo de primeiro ou de segundo grau possa conciliar-se com o âmbito conceitual em que Weber situa a problemática da racionalização. No entanto, Weber faz restrições relativistas. Elas se devem a um motivo que só teria deixado de existir se Weber não tivesse atribuído o que há de especial no racionalismo ocidental a uma peculiaridade cultural, e sim ao modelo seletivo que os processos de racionalização assumiram sob as condições do capitalismo moderno (HABERMAS, 2012a, p. 325-326; os destaques são de Habermas) $)^{2}$.

Entre outras coisas, o que Habermas nos diz agora é que a racionalidade cultural-comunicativa em particular e o processo de modernidade-modernização ocidental como europeização de um modo mais geral não se constituem em princípio-dinâmica meramente contextual ou particularista, não sendo, portanto, exclusivos, singulares e particulares apenas à Europa, mas ao gênero humano como um todo e a cada sociedade-cultura em particular. A Europa não é uma estrutura societal-cultural-cognitiva contextualista ou particularista, não é determinação do - e prisão ao - contexto sociocultural de emergência, mas pleno, pujante e efetivo universalismo pós-tradicional via racionalização culturalcomunicativa, e isso significa, então, que, na verdade, ela é o exemplo evolutivo do próprio processo de desenvolvimento humano em geral e de cada sociedade-cultura em particular, tendo alcançado pela primeira vez esse nível pós-tradicional via racionalização cultural-comunicativa que, no fim das contas, será também alcançado pelos outros da modernidade ao longo do tempo com mais ou menos intensidade. Assim, a estrutura societal-cultural-cognitiva moderna ou europeia não se refere a uma perspectiva etnocêntrica e egocêntrica, a uma forma humana particular e contextualista histórica e geograficamente localizada como Europa e definida normativamente como modernidade-modernização, mas exatamente à universalidade de todo o gênero humano, de modo que ela fala e legitima desde a perspectiva de todo o gênero humano, tendo a universalidade do gênero humano como base orientadora e delimitadora: lembremos de Weber e a ideia de que o sujeito europeu pensa-age-legitima desde um universalismo histórico, corroborada por Habermas e por Honneth). Os outros da modernidade não são universais, mas particulares e contextualistas, embora, como podemos perceber agora, tenham a tendência incipiente à racionalização e, então, à modernização; a modernidade europeia é universal, e não particular ou contextualista, já consolidada nesse movimento evolutivo detonado e realizado em termos de racionalização sociocultural. Isso implica em um triplo ponto que se constitui no fecho de abóboda desse dualismo antropológico europeu e que resume tudo o que se disse aqui em torno a ele: (a) a modernidade-modernização europeia chegou antes ao universalismo pós-tradicional via racionalização cultural-comunicativa e diferenciação social-normativa, mas essa tendência à racionalização é fundacional a todas e a cada uma das sociedades-culturas-consciências humanas; (b) pode-se, então, falar no gênero humano como um todo e defini-lo enquanto um grande processo de modernização ou de europeização através da consecução e da maturação gradativa da racionalidade cultural-comunicativa e 
da diferenciação social-normativa, o que levará ao universalismo pós-tradicional, não-etnocêntrico e não-egocêntrico, sob a forma do procedimentalismo imparcial, impessoal e neutro demarcado pela radical simetria e pela efetiva horizontalidade humana; e (c) os outros da modernidade, que já são protomodernidade, alcançarão gradativamente essa condição moderna e modernizante, tornando-se Europas "de cor" e, com isso, dando razão à pressuposição da Europa acerca de si mesma como apogeu e condição presente do gênero humano, como resultado último da evolução do gênero humano enquanto apagamento dos outros da modernidade como passado antropológico e, então, consolidação da modernidade-modernização ocidental como a destinação básica do gênero humano. Mais uma vez, por meio do dualismo antropológico, nenhuma palavra sobre a tríade eurocentrismo-colonialismo-racismo e/ como fascismo; povos pré-modernos estão ossificados, imobilizados e travados e são atrasados por causa de sua visão de mundo, de sua estrutura societal-cultural-cognitiva arcaica, primitiva, mítica, tradicional, e não por causa da própria modernidade-modernização europeia em termos de sua expansão globalizante como eurocentrismo-colonialismo-racismo e/como fascismo. Mas, ao mesmo tempo, todas as sociedades-culturas não-modernas estão direcionadas, pela sua estrutura interna constituída e dinamizada em termos de racionalidade cultural-comunicativa, a alcançar graus mínimos de modernização ao estilo da Europa, ela que chegou antes, por sua própria estruturação interna, a esse estágio de um universalismo pós-tradicional, não-etnocêntrico e não-egocêntrico. Ora, é aqui que emerge a descolonização africana e a sua visibilização - e desconstrução - do dualismo antropológico, da cegueira histórico-sociológica e da romantização filosófico-normativa do racionalismo ocidental.

\section{O DUALISMO ANTROPOLÓGICO COMO HERANÇA DO EUROCENTRISMO- COLONIALISMO-RACISMO: A CRÍTICA DA MODERNIDADE PELA DESCOLONIZAÇÃO AFRICANA}

O primeiro ponto importante para se entender a descolonização africana, enquanto perspectiva teórica de crítica à modernidade e, mais ainda, em termos de revolução prático-política contra a colonização eurocêntrica e o racismo estrutural diz respeito ao fato de que somente há negro-negritude por causa exatamente da Europa e em termos da triade eurocentrismo-colonialismo-racismo e/como fascismo. Não há aqui, dualismo antropológico entre Europa como singularidade absoluta e todos os outros da Europa como generalização insossa e indiferenciada, não há o negro essencial e sempre genérico; e, no mesmo diapasão, não há nem um processo de modernidade-modernização europeu demarcado por purismo, internalidade, endogenia, autorreferencialidade, autossubsistência e autossuficiência absolutos e nem uma causa cultural da imobilização, da ossificação, do travamento e do "atraso" do negro/negritude/África em relação ao branco e à branquitude/Europa. A superioridade da Europa não se deve (apenas) à sua cultura racionalizada, mas ao colonialismo; o atraso, o imobilismo e o travamento histórico-políticos dos povos negros não se devem à sua cultura mítica, deficitária no que tange à racionalização, mas à Europa e em termos do eurocentrismo-colonialismo-racismo e/como fascismo. Da mesma forma, o dualismo antropológico enquanto diferença qualitativa e de grau entre a modernidade como presente efetivo, atualidade substantiva e abertura ao futuro e todos os outros da modernidade como passado antropológico se deve ao racismo, e não, mais uma vez, a uma condição antropológica interna, endógena e particular seja à Europa como racionalização, seja às populações negras como mito, arcaísmo e primitivismo. Em suma, como nos diz Fanon, o negro é produção do branco, isto é, da Europa por meio da tríade eurocentrismo-colonialismo-racismo e/como fascismo: "A civilização branca, a cultura europeia impuseram ao negro um desvio existencial. [...] aquilo que se chama alma negra é frequentemente uma construção do branco" (FANON, 2008, p. 30). O negro (genérico), racialmente constituído e determinado e ausente de história, ossificado no passado enquanto condição pré-moderna e antimoderna, não existe independentemente da tríade eurocentrismocolonialismo-racismo e/como fascismo, senão que é sua produção direta.

Note-se, nesse sentido, que o negro - assim como o "índio" - não pode ser entendido como entidade autônoma, autossubsistente e autorreferencial, inclusive pré-existente, à expansão global da Europa em termos do eurocentrismo-colonialismo-racismo e/como fascismo e, nesse sentido, de que ele é uma produção político-normativa moderna, sob a forma de violência simbólico-material e como menoridade político-cultural, uma produção simbólico-normativa que contou com a ajuda preciosa da filosofia europeia moderna. É aqui que emerge o dualismo antropológico nessa mesma filosofia 
moderna, gerando isso que Fanon chamará como a metafisica colonial ou, de modo mais fiel às suas palavras, as duas metafisicas produzidas pela modernidade-modernização europeia, ao mesmo tempo interseccionadas e em profundo antagonismo, incapazes de síntese dialética e direcionadas à anulação recíproca, que constituem a realidade colonial: o branco e o negro enquanto realidades essenciais, ahistóricas e apolítico-despolitizadas demarcadas pela destruição recíproca e por uma diferenciação absoluta que impede qualquer reciprocidade, qualquer reconhecimento e qualquer interação e que, inclusive, na medida em que é naturalizada e despolitizada pelo dualismo antropológico europeu estilizado para a realidade colonial, se torna arredia a quaisquer crítica, enquadramento, reflexividade e emancipação, transformando-se, portanto, em racismo estrutural, etnocentrismo cultural e autoritarismo político-institucional: branco é branco, como nos diz Charles Darwin, por causa da seleção sexual; negro é negro, como mais uma vez salienta Charles Darwin, por causa da seleção sexual deficitária. É essa metafísica dúplice, da ossificação das identidades racializadas, complementada com um essencialismo etnocêntrico férreo e com um evolucionismo histórico linear, que condena essas realidades estanques e completamente separadas (conforme o racismo estrutural) ao conflito político-histórico próprio ao colonialismo como instrumentalização econômica e violência etnocida-genocida do negro pelo branco. Para começo de conversa, portanto, a descolonização africana, em Frantz Fanon, constata a falsificação própria ao dualismo antropológico (Europa e outros da Europa como realidades estanques, essenciais, autorreferenciais e endógenas, com caráter biológico-étnico totalmente independente), percebendo-o, na verdade, como a base de justificação da dominação colonial sob a forma do racismo estrutural; sem ele, toda a construção colonial seria exatamente ilegítima, porque negros e indígenas seriam assumidos, concebidos, afirmados e tratados em termos de horizontalidade, simetria e universalidade jurídicomorais - com o dualismo antropológico estilizado em termos de racismo estrutural, a diferença entre brancos e negros e as consequentes relações de instrumentalização e de escravização se devem a diferenças biológico-étnicas essencialistas e naturalizadas, isto é, a esse mesmo racismo, sendo anteriores ao próprio "contato", uma questão essencial ao ser negro e ao ser branco (e ao ser indígena, obviamente). Como consequência, conforme repetimos acima, o negro como o outro da modernidade, como o pré-moderno e antimoderno, é construído pela Europa, não existindo fora desse eixo geopolítico demarcado e legitimado por ela. E é esse dualismo antropológico - na linguagem de Frantz Fanon, as duas metafísicas, a branca e a negra - que deve em primeiro lugar ser reflexivizado, desconstruído e destruído pela descolonização africana. Segundo Fanon:

O problema é muito importante. Pretendemos nada mais nada menos liberar o homem de cor de si próprio. Avançaremos lentamente, pois existem dois campos: o branco e o negro. Tenazmente, questionaremos as duas metafísicas e veremos que elas são frequentemente muito destrutivas. [...] O branco está fechado na sua brancura. O negro na sua negrura. Tentaremos determinar as tendências desse duplo narcisismo e as motivações que ele implica. [...] Por mais dolorosa que possa ser esta constatação, somos obrigados a fazê-la: para o negro há apenas um destino. E ele é o branco (FANON, 2008, p. 26-28).

Para o negro, a alteridade é o outro, o branco; para o negro, o padrão referencial é a branquitude, o espelho imagético é o branco, a base da verdade é a raça-cultura branca. O que isso significa? E quais as consequências dessa dupla - mas interligada - metafísica, seja para a interpretação do eurocentrismocolonialismo-racismo e/como fascismo, seja para a constituição e a dinamização da própria descolonização africana? Na passagem em questão, pertencente ao livro Peles negras, máscaras brancas, uma das obras fundacionais do pensamento politico de Fanon, começa-se com uma abordagem psicanalítico-psiquiátrico-psicológica (Fanon é médico psiquiatra) e chega-se exatamente a uma teoria política anticolonial: a psiquê do negro - e do próprio branco - está abalada, sofre de patologias mentais graves e de fuga da realidade não por um problema mental propriamente dito, independente do contexto social em que emerge (ou à revelia dele), mas porque a realidade colonial, calcada no racismo estrutural, é, para Fanon, uma fábrica de doenças mentais. Por isso, para se compreender essas doenças mentais há que se compreender a realidade colonial, assim como a cura daquelas passa pela luta revolucionária contra essa perspectiva do eurocentrismo-colonialismo-racismo e/como fascismo. É nesse sentido que Fanon falou, acima, de que buscava "liberar o homem de cor de si próprio", isto é, de que há que se destruir o colonialismo-racismo e, portanto, a situação objetiva, institucional, social e normativa que produz o negro (genérico) como coisa, instrumento, animal: eliminar o negro como negro é, na verdade, eliminar o eurocentrismo-colonialismo-racismo e/como fascismo, viabilizando a emergência e o desenvolvimento da liberdade e igualdade e da pluralidade e singularidade humanas e, assim, a 
possiblidade da própria política, da própria intersubjetividade social, que demandam um mínimo de liberdade, de igualdade e de reconhecimento. Note-se, primeiramente, a perspectiva de uma dupla metafísica em termos das sociedades colonizadas enquanto sua base estruturante, legitimadora e dinamizadora: o negro (não) é pelo branco, o branco (como positividade) se afirma pelo negro (como negatividade); o negro é a antitese do branco, o negro é a negatividade absoluta, o polo oposto, contrário e destrutivo relativamente ao qual o branco emerge como positividade, luz, sentido; o negro é o acidente, o branco é a substância (que permite, pela sua objetividade, a interpretação e a definição daquele como incompletude, como parcialidade); o negro é a morte, o branco é a vida; o negro é a selvageria (estado de natureza, como dizia Hobbes; homem natural, como dizia Hegel; sentidos, como dizia Darwin), ao passo que o branco é cultura, civilização, estado civil, razão. É por isso, inclusive, que as duas metafísicas são destrutivas, porque, na verdade, não há síntese - não há reconhecimento - entre o branco e o negro, mas apenas instrumentalização, exclusão e guerra de eliminação absolutas (a própria fusão racial destrói, aqui, a pureza e a supremacia racial e étnica - vide o termo colonial mulato, assim como os casamentos entre indivíduos inferiores, como acreditava Charles Darwin, inviabilizam o melhoramento genético da sociedade) (cf.: DARWIN, 1974). Note-se, em segundo lugar, no que se refere à passagem acima, exatamente a ideia de que o núcleo referencial do sentido e da orientação do negro é o branco, e isso, para Fanon, em um duplo aspecto: de que o negro é produção do branco em termos da tríade eurocentrismo-colonialismo-racismo e/como fascismo e de que as patologias psicossociais coloniais, em termos de uma busca de reprodução do ser branco pelos sujeitos negros (ou da própria imposição da violência reificadora, etnocida e genocida pelo branco), somente podem ser entendidos por meio desse duplo protótipo essencialista e naturalizado do branco senhor e do negro genérico escravizado e inferiorizado, assumido e reproduzido pela colonização. Nesse sentido, mais uma vez, a dupla metafísica colonial se funda, reproduz e tem por consequência um dualismo-maniquéísmo antropológico entre branco como presente e futuro versus o negro como passado, o qual arrasa com a possibilidade de horizontalidade, simetria e reconhecimento e, por conseguinte, que determina essa ideia fanoniana da sociedade colonial como um grande hospital psiquiátrico em que o branco é sempre o centro, o sujeito e a base referenciais por excelência, ao passo que o negro é sempre objeto, instrumento, animalidade a ser controlada por meio da chibata e do arado. Por isso, mais uma vez, o branco é o destino do negro: "Todo mundo já o disse, para o negro a alteridade não é outro negro, é o branco" (FANON, 2008, p. 93). E Fanon complementa:

Compreendemos agora o porquê de o negro não pode se satisfazer no seu isolamento. Para ele, só existe uma porta de saída, que dá no mundo branco. Donde a preocupação permanente em atrair a atenção do branco, esse desejo de ser poderoso como o branco, essa vontade determinada de adquirir as propriedades de revestimento, isto é, a parte de ser e de ter que entram na constituição de um ego. Como dizíamos há pouco, é pelo seu interior que o negro vai tentar alcançar o santuário branco. A atitude revela a intenção. A retração do ego como processo bem sucedido de defesa não é viável para o negro, pois ele precisa da sanção do branco" (FANON, 2008, p. 60).

Essa observação fanoniana é muito importante em sua passagem de uma teoria psicanalíticopsiquiátrica das patologias psicológicas nos sujeitos colonizados-racializados para a constituição de uma perspectiva de descolonização teórico-política como luta anticolonial, porque aponta exatamente para a metafísica colonial enquanto o eixo estruturante de produção e de reprodução permanente de menoridades político-culturais, e, nesse sentido, o dualismo antropológico, como já dizíamos acima, é o ponto fundamental não somente em termos de compreensão da realidade colonial (inclusive da relação entre metrópole e colônia, centro e periferia), mas também a ser desconstruído pela descolonização, porque ele é a causa seja da violência etnocida-genocida e da instrumentalização econômica ampla contra os negros, seja das patologias psicossociais dali surgidas. Note-se, assim, a parte final da citação acima, em que Fanon aponta exatamente para o fato de que o dualismo antropológico não pode ser compreendido e nem resolvido a contento por uma análise psicanalítico-psiquiátrica que situe no sujeito negro individualizado o problema e a causa desse mesmo problema a ser resolvido. É a sociedade colonial que causa as patologias psicossociais ao negro (e ao branco) e, portanto, é a luta política que se constitui na práxis corretiva e emancipatória do grupo-sujeito racializado (cf.: FANON, 1968, p. 254; FANON, 2008, p. 28 , p. 82, p. 186). Essa correlação entre psiquiatria e política, essa passagem da análise psicológica para a análise sociológico-histórica é muito importante porque, se, no caso do dualismo antropológico europeu, temos por consequência a cegueira histórico-sociológica relativamente 
ao processo de modernidade-modernização ocidental e a consequente romantização normativo-filosófica do racionalismo ocidental, na colônia, mais uma vez por meio da afirmação desse dualismo antropológico, temos a consolidação de uma sociedade maniqueísta demarcada pela ausência de mediações, de reconhecimento e de reciprocidade que descamba para a instrumentalização e para a violência diretas. Se, na reflexão metropolitana, a consequência do dualismo antropológico entre modernidade como presente e abertura ao futuro, como racionalização e universalismo pós-tradicional, como crítica, reflexividade, mobilidade e transformação, e todos os outros da modernidade como passado antropológico ossificado, como mito e contextualismo-particularismo, como dogmatismo, fundamentalismo, imobilismo e travamento no espaço e no tempo histórico-políticos, consiste exatamente na invisibilização, no silenciamento e na exclusão do colonialismo, bem como na deslegitimação normativa dos outros da modernidade, nas colônias esse mesmo dualismo antropológico, que aqui se funda no racismo estrutural e o reproduz, leva diretamente à imobilização, ao travamento, à ossificação, à instrumentalização e, como coroamento da "relação" entre colono e colonizado, à violência pungentes. $\mathrm{O}$ dualismo antropológico europeu gera, nas colônias, uma situação de instrumentalização e de violência etnocida-genocida amplas que transforma essa mesma sociedade colonial em uma perspectiva maniqueísta absoluta, cujo resultado é a escravização e a morte.

O mundo colonial é um mundo dividido em compartimentos. Sem dúvida, é supérfluo, no plano da descrição, lembrar a existência de cidades indígenas e cidades europeias, de escolas para indígenas e escolas para europeus, como é supérfluo lembrar o apartheid na África do Sul. O mundo colonizado é um mundo cindido em dois. A linha divisória, a fronteira, é indicada pelos quarteis e delegacias de polícia. Nas colônias, o interlocutor legal e institucional do colonizado é o gendarme ou o soldado. Nas sociedades de tipo capitalista, o ensino religioso ou leigo, a formação de reflexos morais transmissiveis de pai para filho, a honestidade exemplar de operários condecorados ao cabo de cinquenta anos de bons e leais serviços, o amor estimulado da harmonia e da prudência, formas estéticas de respeito pela ordem estabelecida, criam em torno do explorado uma atmosfera de submissão e inibição que torna consideravelmente mais leve a tarefa das forças da ordem. Nas regiões coloniais, ao contrário, o gendarme e o soldado, por sua presença imediata, por suas intervenções diretas e frequentes, mantêm contato com o colonizado e o aconselham, a coronhadas ou com explosões de napalm, a não se mexer. Vê-se que o intermediário do poder utiliza uma linguagem de pura violência. $\mathrm{O}$ intermediário não torna mais leva a opressão, não dissimula a dominação. Exibe-as, manifesta-as com a boa consciência das forças da ordem. $\mathrm{O}$ intermediário leva a violência à casa e à consciência do colonizado (FANON, 1968, p. 27-28).

A sociedade colonial é uma sociedade sem mediações, ao contrário da sociedade metropolitana, porque o racismo estrutural destrói, como estamos dizendo, qualquer simetria, qualquer horizontalidade e qualquer reconhecimento recíprocos, levando à constituição de instituições elas mesmas dualistas, conforme o exemplo do apartheid acima citado - ao contrário exatamente da sociedade metropolitana, em que os direitos do homem geram seja um universalismo horizontalizado, seja instituições e formas de mediação jurídica que garantem equidade, representação e mesmo refreamento do poder. $\mathrm{O}$ maniquésmo colonial, portanto, fundado no dualismo antropológico demarcado e dinamizado em termos de racismo estrutural (branco versus negro), forma, legitima e sustenta um regime de apartheid que se ramifica em dois pontos constitutivos básicos à/na sociedade colonial: a constituição de realidades separadas, estanques e imobilizadas, o espaço do e para o branco, o espaço do e para o negro, sem qualquer intersecção e fusão; e uma assimetria jurídico-institucional em que o branco é sujeito de direitos e de mediações institucionais, enquanto que o negro é, como instrumento, menoridade e nãosujeito, submetido à violência direta. É nesse sentido que Fanon nos falou, primeiramente, na cisão e na compartimentação da sociedade colonial entre cidades europeias versus cidades indígenas enquanto a base de constituição dessa mesma estrutura colonial; e é nesse sentido, em segundo lugar, que ele também nos falou que o árbitro e o princípio mediador dos grupos-sujeitos negros, na colônia, é a violência (o soldado, o gendarme), e não as instituições, a lei, o direito, o devido processo legal. $\mathrm{O}$ importante, nessa comparação entre a sociedade metropolitana enquanto uma sociedade de mediações e a sociedade colonial enquanto uma sociedade maniqueísta sem mediações consiste exatamente no dualismo antropológico moderno e pré-moderno que se ramifica em dualismo, cisão e contraposição entre branco versus negro/indígena, via afirmação do racismo estrutural e do etnocentrismo forte (e, em geral, também do fundamentalismo religioso). É no racismo estrutural que se funda a relação metrópole e colônia, modernidade e pré-modernidade e, assim, é nele e desde ele que se embasa, se desenvolve e se 
dinamiza toda a sociedade colonial enquanto essa sociedade sem mediações demarcada pela violência direta e pela instrumentalização absoluta do grupo-sujeito racializado, dualismo esse que é a condição de existência, de inteligibilidade e de sentido da modernidade-modernização ocidental em sua expansão universal como eurocentrismo-colonialismo-racismo e/como fascismo. A base do dualismo antropológico é o racismo estrutural e sua consequência é exatamente uma perspectiva de maniqueísmo politico-moral radicalizado, do qual o apartheid e a segregação raciais são exemplos claros e, o que é pior, convivendo lado a lado com um regime jurídico-constitucional-cultural aparentemente universalista para os brancos, concomitante à violência policial-institucional contra os negros - por isso, inclusive, pudemos ver na passagem acima que o negro (genérico) é "aconselhado" por bastão, tiro e napalm "a não se mexer", ficando no seu lugar (racial, naturalizado, a-histórico, apolítico-despolitizado). Fanon complementa:

A zona habitada pelos colonizados não é complementar da zona habitada pelos colonos. Estas duas zonas se opõem, mas não em função de uma unidade superior. Regidas por uma lógica puramente aristotélica, obedecem ao princípio da exclusão recíproca: não há conciliação possivel, um dos termos é demais. A cidade do colono é uma cidade sólida, toda de pedra e ferro. É uma cidade iluminada, asfaltada, onde os caixotes de lixo regurgitam de sobras desconhecidas, jamais vistas, nem mesmo sondadas. Os pés do colono nunca estão à mostra, salvo talvez no mar, mas nunca ninguém está bastante próximo deles. [...] as ruas de sua cidade são limpas, sem buracos, sem seixos. A cidade do colono é uma cidade saciada [...]. A cidade do colono é uma cidade de brancos, de estrangeiros. A cidade do colonizado, ou pelo menos a cidade indígena, a médina, a reserva, é um lugar mal afamado, povoado de homens mal afamados. Aí se nasce não importa onde, não importa como. Morre-se não importa onde, não importa de quê. É um mundo sem intervalos, onde os homens estão uns sobre os outros, as casas umas sobre as outras. A cidade do colonizado é uma cidade faminta, faminta de pão, de carne, de sapatos, de carvão, de luz. A cidade do colonizado é uma cidade acocorada, uma cidade ajoelhada, uma cidade acuada. É uma cidade de negros, de árabes. Este mundo dividido em compartimentos, este mundo cindido em dois, é habitado por espécies diferentes. A originalidade do contexto colonial reside em que as realidades econômicas, as desigualdades, a enorme diferença dos modos de vida não logram nunca mascarar as realidades humanas. Quando se observa em sua imediatidade o contexto colonial, verifica-se que o que retalha o mundo é, antes de mais nada, o fato de pertencer ou não a tal espécie, a tal raça. Nas colônias, a infraestrutura econômica é ao mesmo tempo uma superestrutura. A causa é consequência: o individuo é rico porque é branco, é branco porque é rico (FANON, 1968, p. 29).

Ressaltamos, da passagem acima, três afirmações fundacionais, que aparecem interrelacionadas, interdependentes: (a) a sociedade colonial como estando divida em compartimentos estanques e imóveis, aparentemente autorreferenciais, mas organizados de modo sobreposto, o colono sobre o colonizado; (b) a não possibilidade de conciliação, de mediação e de contato recíproco; e (c) a compartimentalização social-institucional-normativa em espécies, isto é, em raças. Percebe-se, assim, a ideia de que a sociedade colonial, calcada no dualismo antropológico determinado em termos de racismo estrutural e de etnocentrismo cultural, se constitui como uma perspectiva dualista-maniquésta que, por um lado, estabelece uma cisão absoluta entre brancos e negros (e o racismo é exatamente essa cisão e essa contraposição absolutas); por outro, estabelece uma relação verticalizada, de cima para baixo, entre o branco como sujeito e o negro como objeto; finalmente, como coroamento desse dualismo-maniquéísmo e dessa relação de instrumentalidade e escravização, tem-se que o único tipo de "relacionalidade" possível é a submissão pela violência, em um duplo aspecto: o negro (genérico), racializado, como nãosujeito, não é detentor de direitos e garantias fundamentais e, portanto, sobre ele não recai nenhuma mediação jurídico-institucional e nenhum refreamento e nenhuma reflexividade pelo poder, mas apenas a violência direta; a violência direta perde o sentido de violação da integridade e transforma-se em simples gesto/postura instrumental, na medida em que o racismo estrutural, ao transformar o negro em questão biológica, em animalidade, em coisa, legitima uma sociedade sem mediações para eles, frente a eles como não-sujeitos. Por isso, para Fanon, todos os aspectos conjunturais da colônia se fundam no - e se dinamizam pelo - racismo estrutural, a pertença a esta ou àquela espécie, o (não)ser negro e o ser branco. $\mathrm{O}$ racismo estrutural torna-se o princípio definidor e, assim, também a plataforma explicativa tanto da relação entre metrópole e colônia quanto da própria organização interna da colônia como um todo. Notese, por consequência, que o racismo estrutural constitui-se na base fundacional e orientadora do dualismo antropológico que preside a metafísica colonial, caracterizada como dualismo-maniqueísmo 
mortal, destrutivo e instrumentalizador entre o negro e o branco, situação que não possibilita seja a conciliação (posto que, no racismo, a conciliação é destruição da pureza racial e étnica como miscigenação; e, na luta anticolonial, não se tolera, não se concilia e nem se consensua com o racismo, mas se o destrói, porque aqui está a causa do colonialismo como degeneração humana), seja a transformação sociopolitica dessa mesma colônia. A racialização é a condição originária e dinamizadora do imobilismo, da ossificação e do travamento da sociedade colonial, compartimentada, segregada/ segregacionista, instrumentalizadora e violenta. Mais uma vez, Frantz Fanon nos diz:

Mundo compartimentado, maniqueísta, imóvel, mundo de estátuas: a estátua do general que efetuou a conquista, a estátua do engenheiro que construiu a ponte. Mundo seguro de si, que esmaga com suas pedras os lombos esfolados pelo chicote. Eis o mundo colonial. O indígena é um ser encurralado, o apartheid é apenas uma modalidade na compartimentação do mundo colonial. A primeira coisa que o indígena aprende é a ficar no seu lugar, não ultrapassar os limites (FANON, 1968, p. 39. Cf. ainda: FANON, 2008, p. 56).

Perceba-se, na passagem acima, a ideia de que o indígena "aprende" a ficar no seu lugar, a não ultrapassar os limites desse mundo compartimentado que é justificado não pela política, mas pela biologia, não pela ação humana, mas pela raça, pelas qualidades essencialistas e naturalizadas de cada povo-sujeito, as quais antecedem o próprio contato (por isso, nas metáforas da colonização, o "desbravador" vem trazer a luz da civilização, da cultura e da razão a quem ainda é um papel em branco ou vive na perdição da selvageria, não conseguindo por si mesmo - às vezes sequer querendo por desejo próprio - sair desse estado selvagem/depravado). Note-se, assim, que a descolonização africana, por meio da afirmação da tríade eurocentrismo-colonialismo-racismo, traz para novo plano a explicação sobre a evolução societal-cultural-cognitiva de cada grupo humano que vimos, na primeira parte do texto, enquanto sendo a tônica da constituição do discurso filosófico-sociológico-antropológico europeu e, nesse caso, em termos de justificação, via dualismo antropológico, da estratificação humana em uma escala evolutiva que vai do tradicionalismo à modernidade-modernização por meio da ideia de que essa mesma evolução, que é específica ou particularizada a cada sociedade-cultura, se deve a princípios internos a ela - a razão para a Europa como causa/explicação de seu sucesso, o mito para todos os outros da Europa como causa/explicação de seu fracasso. Nesse sentido, portanto, a descolonização africana traz para outro plano a explicação seja do processo de modernidade-modernização europeu, recusando sua endogenia, sua independência, sua autonomia e sua autorreferencialidade em relação ao eurocentrismo-colonialismo-racismo e/como fascismo, seja da constituição de todos os outros da Europa como tradicionalismo em geral, isto é, como generalização e indiferenciação antropológicas, o que também significa que a condição como presente substantivo e abertura ao futuro da sociedade-culturaconsciência europeia e a condição como passado evolutivo da sociedade-cultura-consciência nãoeuropeia, a diferença entre modernidade e pré-modernidade são percebidas a partir de um dualismo antropológico cuja raiz é o colonialismo e cujo princípio explicativo e dinamizador é exatamente o racismo estrutural. Por isso mesmo, o atraso, a imobilização, a ossificação e o travamento evolutivos dos povos não-europeus, em particular da África (e da América), não se devem à condição mítico-tradicional de sua sociedade-cultura-consciência, mas ao eurocentrismo-colonialismo-racismo, assim como a supremacia da Europa se deve exatamente a esse mesmo eurocentrismo-colonialismo-racismo. Ora, o grupo-sujeito racializado, instrumentalizado e escravizado, na medida em que se assume como vozpráxis política e politizante, permite uma crítica e uma reorientação da modernidade que, devido ao seu (da Europa) dualismo antropológico, à sua cegueira histórico-sociológica e à sua romantização normativo-filosófica do racionalismo ocidental, não tem condições de ser levada a efeito de modo pleno por parte do próprio aparato paradigmático-normativo europeu, porque prende a postura epistemológicopolítica moderna a uma herança eurocêntrica, colonial e racista que somente pode ser corrigida com o abandono do dualismo antropológico, o reconhecimento do eurocentrismo-colonialismo-racismo e a centralidade do lugar de fala negro-indígena (lembramos apenas que, em Habermas, na sua teoria da modernidade como universalismo pós-tradicional, não aparece uma única vez sequer a menção do eurocentrismo-colonialismo-racismo). É por isso, aliás, que, para Fanon, o grupo-sujeito colonizado é e representa uma condição por excelência política, porque, na sua dupla condição, como singularidade étnica e como construção enquanto menoridade por meio do eurocentrismo-colonialismo-racismo, tem condições de reconstruir e de reorientar o processo de modernidade-modernização europeu em sua expansão universalista totalizante e instrumentalizadora: "O colonizado, o homem subdesenvolvido são hoje animais políticos no sentido mais planetário do termo" (FANON, 1968, p. 62-63). Por outras 
palavras, o grupo-sujeito colonizado é e instaura efetivamente a condição universalista desde a qual se pode enquadrar e reorientar o processo de modernidade-modernização ocidental em um sentido verdadeiramente anticolonial, antifascista, antitotalitário, não-fundamentalista e antirracista, construindo de modo pujante esse universalismo não-etnocêntrico e não-egocêntrico necessário a um mundo plural. A partir desse argumento do grupo-sujeito marginalizado como pleno universalismo que engloba essa 132 perspectiva da diferença e da singularidade antropológica e as experiências de marginalização, de exclusão e de violência enquanto minorias político-culturais produzidas pela tríade eurocentrismocolonialismo-racismo, gostariamos agora de desenvolver quatro ideias importantes apresentadas pela descolonização africana em termos de crítica da modernidade como desconstrução do dualismo antropológico calcado nesse mesmo eurocentrismo-colonialismo-racismo e/como fascismo: primeiramente, reforçando essa perspectiva de que o negro é uma produção caudatária do racismo; segundo, a ideia de uma superação da clausura da raça como base estruturante da luta anticolonial, uma vez que o racismo é o núcleo constitutivo e dinamizador da modernidade-modernização europeia em termos de dualismo antropológico e, nesse caso, se manifesta nas colônias como maniqueísmo políticomoral-cultural e violência simbólico-material direta; em terceiro lugar, a renomeação da história da modernidade-modernização europeia em sua expansão global exatamente em termos dessa tríade eurocentrismo-colonialismo-racismo e/como fascismo; e, finalmente, em um quarto momento, a definição do lugar de fala negro-indígena, nessa sua intersecção de singularidade e diferença antropológica e de experiência objetiva de marginalização por meio do racismo europeu, enquanto tendo condições de oferecer e de fundar um novo universalismo com caráter anticolonial, antifascista, antitotalitário, não-fundamentalista e antirracista.

Em primeiro lugar, como vimos falando ao longo desta segunda parte, é importante considerarmos que, ao contrário do dualismo antropológico europeu, que serve de base para a constituição de seu discurso filosófico-sociológico-antropológico da modernidade-modernização europeia como universalismo pós-tradicional via racionalidade cultural-comunicativa, e que parte da cisão, da independência, da separação, da autonomia, da endogenia, da autorreferencialidade, da autossubsistência, da autossuficiência e da sobreposição da modernidade em relação a todos os outros da modernidade, explicando-se, assim, a singularidade da Europa e de todos os outros da Europa por princípios internos a cada uma destas realidades antropológicas, a descolonização africana insistirá que o sentido da colônia e, nesse caso, do negro (genérico) e do índio (genérico) somente existe por causa da tríade eurocentrismo-colonialismo-racismo e/como fascismo, ou seja, é uma construção, baseada em violência simbólico-material, da Europa em sua expansão universal como usurpação, reificação, produção de minorias político-culturais e realização de etnocídio-genocídios práticos. Nesse sentido, o dualismo antropológico é fundado no racismo estrutural, no etnocentrismo cultural, no instrumentalismo econômico e, inclusive, no fundamentalismo religioso, tendo por objetivo animalizar, despersonalizar e reificar os outros da modernidade que, assim, como meras coisas, meras bestas, meros papeis em branco, simplesmente poderiam ser subjugados, utilizados a bel prazer, evangelizados/civilizados e guiados ou mesmo, ao fim e ao cabo, assassinados. O dualismo antropológico entre razão e corpo, mente e sentidos, estado civil e estado de natureza, cultura e natureza, civilização e barbárie e, hodiernamente, moderno e pré-moderno, razão e mito, pós-tradicional e tradicional se constitui no princípio estruturante, dinamizador e contínuo dessa manutenção da colonialidade epistêmico-cultural e, obviamente, políticoeconômica da modernidade-modernização ocidental em relação aos outros da modernidade, inclusive levando seja ao silenciamento, à invisibilização e ao apagamento do eurocentrismo-colonialismoracismo das e pelas teorias da modernidade, do e pelo discurso filosófico-sociológico-antropológico da modernidade, seja à deslegitimação dos outros da modernidade como passado antropológico e condição pré-moderna e antimoderna. Como também dissemos acima, na colônia esse dualismo antropológico se materializa em maniqueísmo político-moral, gerando uma sociedade estratificada, compartimentada, ossificada, imóvel, travada e atrasada, demarcada pela ausência de mediações e, então, pela violência simbólico-material direta e permanente contra os grupos-sujeitos escravizados. Nesse sentido, como afirma Fanon, "A inferiorização é o correlato nativo da superiorização europeia. Precisamos ter coragem de dizer: é o racista que cria o inferiorizado" (Fanon, 2008, p. 90; os destaques são de Fanon). E ele complementa relativamente à luta anticolonial contra a tríade eurocentrismo-colonialismo-racismo e/ como fascismo:

A descolonização é o encontro de duas forças congenitamente antagônicas que extraem sua originalidade precisamente dessa espécie de substantificação que segrega e alimenta a situação 
colonial. Sua primeira confrontação se desenrolou sob o signo da violência, e sua coabitação - ou melhor, a exploração do colonizado pelo colono - foi levada a cabo com grande reforço de baionetas e canhões. O colono e o colonizado são velhos conhecidos. E, de fato, o colono tem razão quando diz que 'os' conhece. É o colono que fez e continua a fazer o colonizado. O colono tira a sua verdade, isto é, os seus bens, do sistema colonial (FANON, 1968, p. 26; os destaques são de Fanon).

Note-se, em primeiro lugar nessa passagem, a argumentação fanoniana em torno ao fato de que essa condição dualista-maniqueísta calcada no racismo estrutural, que ao mesmo tempo imbrica e separa-antagoniza essencialmente ao branco e ao negro/indígena (o branco é o senhor do indígena e este é o instrumento daquele; o branco não é essencialmente o indígena, o indígena não é essencialmente ao branco; o branco destrói o indígena, o indígena destrói o branco), se deve a uma realidade objetiva que é exatamente o colonialismo, não existindo independentemente dele e, na verdade, sendo a sua condição de possibilidade: essa racialização do mundo é a base estruturante do colonialismo e somente faz sentido quando se substantiva, isto é, quando se objetiva o mundo colonial como dualismo-maniqueísmo antropológico-normativo. Perceba-se, então, em segundo lugar e por consequência, que é o colonialismo que produz o grupo-sujeito colonizado, fazendo-o por meio desse dualismo antropológico que leva ao maniquéismo político-cultural. Nesse caso, em terceiro lugar, a violência simbólico-material direta, imediada e imediata é o que caracteriza a consolidação e o desenvolvimento do colonialismo ao longo do tempo, demarcando toda a dinâmica colonial do início ao fim não só como uma grande fábrica de doenças mentais, mas, antes de tudo e como condição para tudo o mais, como uma condição intersubjetiva e institucional fundada na - reprodutora da - violência simbólico-material permanente e pungente, da segregação e da compartimentalização raciais absolutas e, finalmente, da ossificação, do travamento e da imobilização da sociedade (cada um no seu lugar permanentemente). Nesse sentido, para Fanon, o colonialismo, por meio do dualismo antropológico constituído como racismo estrutural, apaga a história e a cultura dos sujeitos colonizados e, assim, se constitui no verdadeiro princípio explicativo de sua imobilidade, de seu travamento, de sua ossificação e de seu atraso histórico-políticos. Ele diz:

O domínio colonial, porque total e simplificador, logo fez com que se desarticulasse de modo espetacular a existência cultural do povo subjugado. A negação da realidade nacional, as novas relações jurídicas introduzidas pela potência ocupante, o lançamento à periferia, pela sociedade colonial, dos indígenas e seus costumes, a usurpação, a escravização sistematizada dos homens e das mulheres tornam possível essa obliteração cultural.

A situação colonial determina, em sua quase totalidade, a cultura nacional. Não há, não poderia haver, cultura nacional, vida cultural nacional, invenções culturais ou transformações culturais nacionais no quadro de um domínio colonial. Aqui e ali surgem às vezes tentativas ousadas de reativar o dinamismo cultural, de reorientar os temas, as formas, as tonalidades. $\mathrm{O}$ interesse imediato, palpável, evidente de tais sobressaltos é nulo. [...]

A cultura nacional é, sob o domínio colonial, uma cultura contestada, cuja destruição é empreendida de maneira sistemática. É muito rapidamente uma cultura condenada à clandestinidade. Essa ideia de clandestinidade é imediatamente percebida nas reações do ocupante, que interpreta a complacência nas tradições como uma fidelidade ao espírito nacional, como uma recusa à submissão. A persistência nas formas culturais condenadas pela sociedade colonial é já uma manifestação nacional. Mas essa manifestação é anulada pelas leis da inércia. Não há ofensiva, não há redefinição das relações. Há crispação em um núcleo cada vez mais estreito, cada vez mais inerte, cada vez mais vazio.

Ao cabo de um ou dois séculos de exploração produz-se uma verdadeira emaciação do panorama cultural nacional. A cultura nacional converte-se em um estoque de hábitos motores, de tradições indumentárias, de instituições fracionadas. Observa-se pouca mobilidade. Não há criatividade genuína, não há efervescência. Miséria do povo, opressão nacional e inibição da cultura são uma só e mesma coisa. Após um século de domínio colonial, encontra-se uma cultura de extrema rigidez, sedimentada, mineralizada. O desaparecimento da realidade nacional e a agonia da cultura nacional mantêm relações de dependência recíproca (FANON, 1968, p. 197199).

Ora, é o racismo estrutural que ossifica e imobiliza a sociedade colonial em um tempo ahistórico e em uma fantasmagoria essencialista e naturalizada com caráter imutável: negro sempre será 
negro, branco sempre será branco; branco e negro estão em relação de sobreposição e de dependência (sujeito-objeto, sujeito que usa objetos, objeto que só é inteligido pelo sujeito), mas também de cisão e de antagonismo absolutos. Ademais, a racialização é e implica em verticalização e assimetria do desenvolvimento do gênero humano em uma escala evolutiva estratificada e hierárquica, do menos para o mais, do passado para o presente - o presente como condição de inteligibilidade do passado, o passado 134 como incapaz de presentificação e, finalmente, somente o presente podendo conduzir ao futuro, abrir e definir o caminho ao futuro. E, nesse caso, o branco, a branquitude e a Europa são colocados exatamente como esse apogeu, como essa condição presente que, enquanto tal, enquadra, mensura, avalia e define o sentido do negro e do índio enquanto passado antropológico, enquanto animalidade, ausente de civilização, incapaz de cultura. É o racismo biológico que, enquanto base estruturante, dinamizadora e definidora do colonialismo, ao implantar o dualismo antropológico e, assim, ao constituir um maniquéismo político-institucional demarcado por segregação, ausência de mediações, recusa de reconhecimento e violência simbólico-material direta, aponta para a naturalização da realidade colonial como apartheid, da segregação social como separação e superiorização-inferiorização raciais e, então, como travamento, imobilismo, ossificação e imutabilidade desses mesmos papeis, dessas mesmas relações e desses mesmos valores sociais. $\mathrm{O}$ dualismo antropológico e o maniqueísmo político-cultural instaurados pelo racismo estrutural, com isso, não só definem essa dependência (sujeito-objeto), essa separação (modernidade e todos os outros da modernidade, branco-branquitude-Europa versus negroíndio-pré-modernidade), essa centralidade paradigmática da modernidade frente ao pré-moderno (somente ela gera e fomenta racionalidade-racionalização, crítica, mobilidade, reflexividade e emancipação, ao passo que todos os outros da modernidade, por sua estrutura mítica, não geram crítica, reflexividade e transformação, ficando imóveis e sendo dogmáticos ao longo do tempo) e essa contraposição e essa não-conciliação absolutas (modernidade como presente substantivo e abertura ao futuro versus todos os outros da modernidade como passado antropológico) assumidas pelas teorias da modernidade europeias, senão que, no nível prático-político-histórico, produzem e reproduzem, por meio da violência simbólico-material, minorias político-culturais genéricas, ossificadas e imutáveis (por suas próprias causas internas), despolitizando o colonialismo, mantendo cega a autoconsciência normativa europeia. Por isso, para a descolonização africana, a emancipação humana somente pode ser viabilizada pela destruição do dualismo antropológico e do maniqueísmo político-moral determinados em termos de racismo estrutural. Sair da clausura da raça, eliminar a clausura da raça, nesse sentido, é a grande invectiva assumida, fomentada e efetivada pela descolonização africana. Sobre isso, diz-nos Achille Mbembe:

Para Fanon, essa ascensão em humanidade só pode resultar de uma luta: a luta pela vida. Essa luta - igual à luta pela eclosão do mundo - consiste em forjar essa capacidade de ser si mesmo, de atuar por si mesmo e de se erguer por si mesmo que Fanon compara a um surgimento -, surgimento das profundezas daquilo a que chama 'uma região extraordinariamente estéril e árida', essa zona de não ser que, no seu entender, é a raça. Assim, para Fanon, sair das regiões estéreis e áridas da existência é, acima de tudo, sair da clausura da raça - clausura na qual o olhar do Outro e o poder do Outro tentam agrilhoar o sujeito. Contribuindo também para dissipar o espaço das distinções nítidas, das separações, das fronteiras e das clausuras e rumar para o universal que afirma ser "inerente à condição humana" (MBEMBE, 2014, p. 59-60; os destaques são de Mbembe).

Note-se, com isso, que a clausura da raça é pura e simplesmente a despolitização, a ossificação, a imobilização e a imutabilidade entre a modernidade e os outros da modernidade (obviamente por meio de violência epistêmico-política!) que, no colonialismo, explode em cheio no racismo estrutural, levando à consolidação desse dualismo antropológico e desse maniquéismo moral que normalizam e naturalizam não só a assimetria, a separação e a contraposição absolutas entre o moderno (branco-branquitudeEuropa) e o pré-moderno (negro-negritude-África e índio-indianidade-América) e a condição prépolitica, pré-cultural e a-histórica dos sujeitos, dos papeis, dos valores e das relações sociopolíticas (tanto modernos quanto pré-modernos), senão que também legitimam essa sociedade sem mediações demarcada pela violência simbólico-material direta contras as minorias político-culturais. É nesse sentido que a descolonização africana insiste nessa ligação umbilical entre a modernidade-modernização europeia e os outros da modernidade, entre o moderno e o pré-moderno, entre o branco-branquitudeEuropa, o negro/negritude/África e o índio/indianidade/América e, com isso, propõe uma nova compreensão da história e do sentido da modernidade-modernização ocidental ou europeia. Essa nova 
história da modernidade, esse discurso filosófico-sociológico-antropológico da modernidademodernização ocidental parte exatamente das experiências de marginalização, de exclusão e de violência vividas e sofridas pelos grupos-sujeitos colonizados-racializados, no caso os povos negros e indigenas, como base para a interpretação, para a crítica, para o enquadramento e para a reorientação desse mesmo processo de modernidade-modernização ocidental. Nesse sentido, a descolonização africana definirá a modernidade-modernização ocidental como um processo de expansão universal totalizante fundado na tríade eurocentrismo-colonialismo-racismo e/como fascismo contra os outros da modernidade, que também é dinamizado por uma postura de regressão unidimensional sob a forma do fascismo-totalitarismo-racismo internamente à própria Europa: se, no primeiro caso, europeus instrumentalizaram, usurparam e mataram povos não-europeus, racialmente estruturados, como é o caso do colonialismo, no segundo europeus mataram-se reciprocamente. O mais importante dessa história alternativa da modernidade-modernização ocidental como universalismo, desse discurso-práxis descolonizador/a sobre a modernidade-modernização europeia como universalidade por meio do dualismo antropológico e do maniqueísmo político-moral consiste exatamente na sua associação com o fascismo-totalitarismo, o colonialismo-racismo como a primeira manifestação objetiva e sistemática do fascismo-totalitarismo europeu como modernidade-modernização. Sobre isso, nos diz Aimé Césaire:

Seria preciso estudar, primeiro, como a colonização se esmera em descivilizar o colonizador, em embrutecê-lo, na verdadeira acepção da palavra, em degradá-lo, em despertá-lo para os instintos ocultos, para a cobiça, para a violência, para o ódio racial, para o relativismo moral, e mostrar que, sempre que há uma cabeça degolada e um olho esvaziado no Vietname e que em França se aceita, uma rapariguinha violada e que em França se aceita, um Malgaxe supliciado e que em França se aceita, há uma aquisição de civilização que pesa com o seu peso morto, uma regressão universal que se opera, uma gangrena que se instala, um foco de infecção que se alastra e que no fim de todos estes tratados violados, de todas estas mentiras propaladas, de todos estes prisioneiros manietados e "interrogados", de todos estes patriotas torturados, no fim desta arrogância racial encorajada, desta jactância ostensiva, há o veneno instilado nas veias da Europa e o progresso lento, mas seguro, do asselvajamento do continente [...]. E, então, em um belo dia, a burguesia é despertada por um ricochete: as gestapos afadigam-se, as prisões enchem-se, os torcionários inventam, requintam, discutem em torno dos cavaletes [...]. As pessoas espantam-se, indignam-se. Dizem: 'Como é curioso! Ora! É o nazismo, isso passa!'. E aguardam, e esperam; e calam em si próprias a verdade - que é uma barbárie, mas a barbárie suprema, a que coroa, a que resume a quotidianidade das barbáries; que é o nazismo, sim, mas que, antes de serem as suas vítimas, foram os cúmplices; que o toleraram, esse mesmo nazismo, antes de o sofrer, absolveramno, fecharam-lhe os olhos, legitimaram-no, porque até aí só se tinha aplicado a povos não europeus; que o cultivaram, são responsáveis por ele, e que ele brota, rompe, goteja, antes de submergir nas suas águas avermelhadas de todas as fissuras da civilização ocidental e cristã [...].Sim, valeria a pena estudar clinicamente, no pormenor, os itinerários de Hitler e do Hitlerismo e revelar ao burguês muito distinto, muito humanista, muito cristão do século XX, que traz em si um Hitler que se ignora, que Hitler vive nele, que Hitler é o seu demônio, que se o vitupera é por falta de lógica, que, no fundo, o que não perdoa a Hitler não é o crime em si, o crime contra o homem, não é a humilhação do homem em si, é o crime contra o homem branco, a humilhação do homem branco e o ter aplicado à Europa processos colonialistas a que até aqui só os árabes da Argélia, os "coolies" da İndia e os negros da África estavam submetidos (CÉSAIRE, 1978, p. 18; os destaques são do autor. Cf., ainda: MEMMI, 1967, p. 63-64; FANON, 1968, p. 191; MBEMBE, 2014b, p. 21-99; WERÁ JECUPÉ, 2002, p. 22; KRENAK, 2015, p. 156-157; QUIJANO, 1992, p. 11-20; QUIJANO, 2005, p. 125-142).

Se em outras passagens desse texto pudemos perceber a ideia de que o mundo colonial e, como consequência, de que o negro/índio racializado são uma produção da Europa em termos de sua expansão universalizante como eurocentrismo-colonialismo-racismo, pudemos perceber, agora, por essa passagem, seja a correlação de eurocentrismo-colonialismo-racismo e/como fascismo, seja, então, essa interpretação da modernidade-modernização europeia enquanto sendo demarcada por uma dupla e imbrica dinâmica, a saber, a sua expansão universal totalizante enquanto essa tríade eurocentrismocolonialismo-racismo e/como fascismo e a sua regressão unidimensional e massificadora sob a forma, mais uma vez, de fascismo-totalitarismo-racismo. Ora, com isso desvela-se um dos grandes núcleos normativos desde os quais a descolonização africana ganha o seu sentido e a sua orientação em termos 
tanto de construção de uma voz-práxis direta, autoral e revolucionária por parte do grupo-sujeito colonizado quanto de crítica e de reconstrução do discurso filosófico-sociológico-antropológico da modernidade a partir da tríade eurocentrismo-colonialismo-racismo e/como fascismo. Nesse caso, o racismo estrutural não explica apenas a constituição do dualismo antropológico próprio às teorias da modernidade-modernização europeia e, antes de tudo, sua ramificação histórico-politica, no caso das colônias, em um maniquéismo político-moral, em um processo de apartheid social e em uma postura de autoritarismo institucional legitimadores de uma instrumentalização ampla, de uma assimetria absoluta, de uma produção permanente de minorias político-culturais racializadas e, então, de uma perspectiva de etnocídio-genocídio cotidiana contra os povos negros e indígenas; o racismo estrutural explica também a própria emergência dos regimes fascistas e totalitários do século XX no interior da Europa (nazismo alemão, comunismo soviético, fascismo italiano, fascismo franquista, fascismo salazarista etc.), demarcados pela correlação de eugenia, evolucionismo e darwinismo biológicos e de filosofia da história etnocêntrico-salvífica (a pureza racial como futuro, no caso do nazismo; a teodiceia e o fundamentalismo religioso como substrato, no caso da Itália, da Espanha e de Portugal; a luta de classes como princípio estruturante da história, no caso do comunismo soviético, o qual também bebia nessa perspectiva do racismo, do darwinismo e do evolucionismo); finalmente, o racismo biológico explica exatamente essa "falta de lógica" da consciência cognitivo-moral europeia, isto é, de se reprovar o fascismo e de se legitimar - ou pelo menos tolerar - o colonialismo, inclusive por um fato muito óbvio próprio à primeira metade do século XX na Europa: França, Inglaterra e mesmo Estados Unidos lutam contra o fascismo, criam a ONU e a Declaração Universal dos Direitos Humanos e, não obstante, mantêm regimes coloniais e fornecem suporte para inúmeras ditaduras seja no contexto africano, seja no contexto asiático, seja finalmente no contexto americano (o mesmo fazendo a URSS!). Como consequência, a descolonização africana, de modo concomitante à formulação de uma nova história da modernidade-modernização ocidental em termos da tríade eurocentrismo-colonialismo-racismo e/como fascismo, apresenta e defende um novo papel ao grupo-sujeito colonizado enquanto descolonização, isto é, esclarecer o Esclarecimento relativamente ao seu dualismo antropológico, à sua cegueira histórico-sociológica e à romantização normativo-filosófica do racionalismo ocidental. É Frantz Fanon que nos fala novamente:

Trata-se, para o Terceiro Mundo, de recomeçar uma história do homem que tenha em conta ao mesmo tempo as teses às vezes prodigiosas sustentadas pela Europa e também os crimes da Europa, dos quais os mais odiosos terão sido, no interior do homem, o esquartejamento patológico de suas funções e o esmigalhamento de sua unidade no quadro de uma coletividade em que a fratura, a estratificação, as tensões sangrentas alimentadas pelas classes, enfim, na escala imensa da humanidade, os ódios raciais, a escravidão, a exploração e sobretudo o genocídio exangue representam a segregação de um bilhão e meio de homens (FANON, 1968, p. 274).

Note-se, primeiramente, que a descolonização não significa a defesa de uma perspectiva antimoderna e antimodernizante, uma recusa da Europa pura e simplesmente - na verdade, essa cisão, essa endogenia e essa contraposição absolutas são defendidas e foram praticamente promovidas pela cultura moderna e explicitada em toda a sua pungência seja pelas filosofias modernas, seja pelo discurso filosófico-sociológico-antropológico europeu contemporâneo, como vimos em passagens de Habermas na primeira parte desse texto. A descolonização africana tem por base exatamente (a) a emancipação dos/ pelos sujeitos colonizados em relação à tríade eurocentrismo-colonialismo-racismo e/como fascismo, (b) a crítica da modernidade relativamente ao seu dualismo antropológico, à sua cegueira históricosociológica e à sua romantização normativo-filosófica do racionalismo ocidental e, então, (c) a defesa de um universalismo anticolonial, antifascista, antitotalitário, não-fundamentalista e antirracista que encontra na erradicação do eurocentrismo-colonialismo-racismo e/como fascismo seu substrato e seu núcleo dinamizador. É por isso que, segundo Achille Mbembe, a descolonização se concebe, se afirma como poder originário da diferença enquanto positividade, a qual não apenas desconstrói o dualismo antropológico e o maniqueísmo político-cultural modernos como racismo estrutural, via publicização, pelos próprios marginalizados, de suas experiências de exclusão, de menorização e de violência, mas também, desde suas alteridades irredutiveis, gera e sustenta uma condição humana horizontalizada, simétrica e equalizada. Esse, aliás, é o fecho de abóboda da descolonização africana em sua crítica ao dualismo antropológico europeu: o universalismo não-etnocêntrico e não-egocêntrico exige a superação do racismo estrutural e do dualismo e do maniquéismo que ele gera, o que também significa que a consecução dele implica em que os outros da modernidade, por ela produzidos como passado, negatividade e menoridade, esclareçam-na de seu dualismo-maniquéismo antropológico, de sua cegueira 
histórico-sociológica e de sua romantização normativo-filosófica do racionalismo ocidental. Caudatário da tríade eurocentrismo-colonialismo-racismo e/como fascismo, o dualismo antropológico e o maniquésmo político-cultural impedem seja a efetividade da crítica da modernidade e de sua autocompreensão normativa, seja a consequente pretensão de fundar, legitimar, sustentar e impor o universalismo não-etnocêntrico e não-egocêntrico, seja, ainda, a própria pressuposição de juiz e guia do gênero humano como um todo e de cada sociedade-cultura em particular que a modernidademodernização europeia se assume, centraliza e monopoliza por meio de sua autopressuposição enquanto presente efetivo, atualidade substantiva e abertura e direcionamento ao futuro e com sua redução de todos os outros da modernidade a passado antropológico, fundamentalismo-dogmatismo político-moral e imobilismo e ossificação culturais. O Esclarecimento europeu, nesse sentido, terá de ser descolonizado e, certamente, terá de descolonizar-se!

Considerações finais

Como procuramos demonstrar ao longo do texto, o discurso filosófico-sociológicoantropológico contemporâneo da modernidade, especialmente nos autores europeus aqui analisados, assume, mantém e se utiliza fartamente do dualismo antropológico como base de compreensão e de constituição do processo de modernidade-modernização ocidental ou europeu e, ainda, para a construção de uma noção de universalismo epistemológico-moral pós-tradicional que tem na sociedade-culturaconsciência europeia a sua base estruturante, o seu apogeu como presente substantivo e atualidade efetiva e a sua ponta de lança em termos de abertura, definição e orientação ao futuro. Nesse sentido, é esse mesmo dualismo antropológico - no caso, a diferenciação, a separação, a autonomia, a independência, a endogenia, a autorreferencialidade, a autossubsistência, a autossuficiência e a sobreposição da Europa ou modernidade/modernização ocidental em relação a todos os outros da Europa, a diferença, a separação e a contraposição entre a modernidade versus todos os outros da modernidade - que, de um só golpe, funda um processo de modernidade-modernização ocidental encabeçado pela Europa, que parte dela, em termos de superação de sua menoridade como tradicionalismo e de consecução de sua maioridade como racionalização sociocultural, e caminha de modo reto, direto e linear às sociedades do capitalismo tardio, nesse caso Europa ocidental e América do Norte (na época da Guerra Fria denominada de Primeiro Mundo) e o socialismo soviético (na época da Guerra Fria denominado de Segundo Mundo). Ademais, concomitantemente à evolução da Europa desde dentro, por si mesma, desde si mesma e a partir de seus princípios internos estruturantes (racionalização sociocultural em Weber; correlação, separação e tensão-contradição entre modernidade cultural e modernização econômico-social, em Habermas; separação das esferas do reconhecimento da moral, do direito e da política, em Honneth), que, como dissemos acima, vai exatamente às sociedades do capitalismo tardio enquanto perspectiva antropológica pós-tradicional, pós-metafísica, pós-convencional ou descentrada, tem-se a consolidação de três pontos fundamentais ao discurso filosófico-sociológicoantropológico da modernidade-modernização europeia como universalismo pós-tradicional via racionalização sociocultural calcada de modo fundamental no dualismo antropológico modernidade versus todos os outros da modernidade como pré-modernos, a saber: (a) a afirmação de que tanto as causas detonadoras da modernização europeia e, assim, da consolidação dessa mesma Europa como estrutura societal-cultural-cognitiva racionalizada e universalista em nível pós-tradicional, demarcada por reflexividade, criticidade, mobilidade e transformação ao longo do tempo, quanto os fatores constitutivos do atraso, da imobilidade, da ossificação e da imutabilidade dos outros da modernidade como passado evolutivo, contextualismo-particularismo estrito, dogmatismo e fundamentalismo se devem a princípios internos à Europa (razão/racionalização) e a princípios internos a todos os outros da Europa (mito/fundamentalismo/dogmatismo), não havendo qualquer contato e, por isso mesmo, qualquer reciprocidade na constituição dessa assimetria entre a Europa e os outros da Europa; (b) a defesa de que somente a Europa, por meio da centralidade da razão/racionalização sociocultural, a qual leva à desnaturalização, à historicização e à politização da sociedade-cultura-consciência, a qual separa natureza ou mundo objetivo, sociedade-cultura e consciência, a qual separa moral, política e direito, se alcança seja uma perspectiva de crítica, de reflexividade, de mobilidade e de transformação social, seja o universalismo não-etnocêntrico e não-egocêntrico ou universalismo pós-tradicional, de modo que a modernidade-modernização europeia consegue ao mesmo tempo reconstruir-se conscientemente em seu processo formativo, postar-se criticamente sobre si mesma e por si mesma, esclarecer objetivamente suas patologias e transformá-las ativamente ao longo do tempo, esclarecer e enquadrar todos os outros da modernidade como passado antropológico, assumir-se como o sujeito-lugar-condição da crítica, da 
reflexividade, da mobilidade e da transformação (de si e de todos os outros da modernidade, tornando-se a condição central para a objetivação do mundo e do homem) e, então, como presente efetivo e atualidade substantiva, conduzir o gênero humano à sua plena atualização como modernidademodernização, tendo condições, neste último caso, de servir como guarda-chuva normativo por excelência da diversidade humana e de sustentar uma concepção substantiva de direitos humanos capaz de organizar e de orientar a diversidade antropológica ao longo do tempo em suas relacionalidade; e, por meio tanto da contraposição radical, da separação absoluta e do purismo estrito entre modernidade e todos os outros da modernidade como pré-modernidade (com a consequente definição do processo de modernidade-modernização ocidental enquanto uma perspectiva linear que vai da Europa ao capitalismo tardio ou Primeiro e Segundo Mundos) quanto da definição dos outros da modernidade como passado antropológico, fundamentalismo, dogmatismo e contextualismo-particularismo (portanto, com sua imobilização e sua ossificação no passado antropológico como contextualismo-particularismo e fundamentalismo-dogmatismo), (c) o apagamento do e o silenciamento sobre a tríade eurocentrismocolonialismo-racismo e/como fascismo, de modo que, mais uma vez, as causas explicativas seja da pujança da Europa como universalismo pós-tradicional seja do atraso, da imobilidade e da ossificação dos outros da modernidade como passado antropológico se devem sempre e prioritariamente a princípios endógenos a estes dois modelos antropológicos básicos da condição humana, a Europa como modernidade e todos os outros da Europa como pré-modernidade.

Ora, a partir da descolonização africana e, nesse caso, da constituição de uma voz-práxis política e politizante com caráter anticolonial, antirracista e antifascista desde o lugar de fala das minorias político-culturais, do grupo-sujeito negro menorizado que agora se levanta, como nos diz Achille Mbembe, enquanto poder originário da diferença, como pluralização epistêmico-discursiva e como redirecionamento das alternativas relativamente ao processo de modernidade-modernização ocidental, temos uma sólida contraposição ao dualismo antropológico, à cegueira histórico-sociológica e à romantização normativo-fillosófica do racionalismo ocidental, assumidos pelas teorias da modernidade europeias, no sentido de que esse mesmo dualismo e suas consequências, (a) o silenciamento, a invisibilização e o apagamento da tríade eurocentrismo-colonialismo-racismo e/como fascismo e (b) a deslegitimação dos outros da modernidade como passado antropológico, como fundamentalismodogmatismo e contextualismo-particularismo, são resultado exatamente dessa tríade eurocentrismocolonialismo-racismo e/como fascismo, reassumindo-a, reestilizando-a e utilizando-a mais uma vez e como um continuum na história de quinhentos anos de expansão universalizante da Europa em relação a povos não-europeus em termos de usurpação, instrumentalização, produção de menoridades políticoculturais e, finalmente, de cometimento de processos de etnocídio-genocídio planificados contra nãoeuropeus. O dualismo antropológico entre modernidade versus todos os outros da modernidade, entre modernidade como razão e universalismo versus todos os outros da modernidade como mito e tradicionalismo-contextualismo-particularismo, entre Europa como presente substantivo, atualidade efetiva e abertura ao futuro versus todos os outros da Europa como passado antropológico, entre a Europa como autoconsciência, autorreflexividade, mobilidade e transformação versus todos os outros da modernidade como subsunção ao meio natural-cultural totalizante, como consciência-perspectiva mágico-animista e, assim, como imobilismo, ausência de crítica, dogmatismo-fundamentalismo, ossificação, imutabilidade e travamento no passado, esse mesmo dualismo antropológico europeu, como dizíamos, não é uma premissa científico-fática ingênua e utilizada de modo neutro e objetivo, mas simplesmente uma herança colonial fundada na tríade eurocentrismo-colonialismo-racismo e/como fascismo. Como procuramos desenvolver ao longo do tempo, as consequências teórico-práticas da utilização do dualismo antropológico e, nesse caso, do estudo dos povos negros e indígenas e de sua definição como condição-sujeito-valor pré-moderno possibilita, no caso de Weber, de Habermas e de Honneth, a construção não apenas de uma barreira intransponível entre modernidade e todos os outros da modernidade, entre modernidade e pré-modernidade, mas também a defesa seja de uma independência e de um purismo absolutos entre Europa frente a todos os outros da Europa (e destes para com aquela), seja, então, a justificativa das especificidades de cada uma dessas realidades antropológicas por meio de princípios endógenos estritos, seja, finalmente, pelo apagamento, pelo silenciamento e pela invisibilização da tríade eurocentrismo-colonialismo-racismo e/como fascismo enquanto eixo constitutivo, valor estruturante e princípio dinamizador do processo de modernidade-modernização ocidental. Desse modo, por meio do dualismo antropológico europeu, a condição como passado antropológico imobilizado, travado e ossificado no passado e no tempo históricos é explicada 
basicamente por princípios internos à sociedade-cultura dos outros da modernidade, do mesmo modo como a singularidade, a dinâmica e a pujança da Europa são explicadas apenas por princípios internos ínsitos a ela. Não há nenhuma reciprocidade e nenhuma determinação mútua e, finalmente, como estamos insistindo, a tríade eurocentrismo-colonialismo-racismo e/como fascismo assombrosa e explicitamente desaparece da constituição dessa compreensão normativo-empírica de modernidademodernização ocidental que, portanto, passa a ser um evento endógeno à Europa, que tem sua explicação em princípios internos e cujo caminho evolutivo vai às sociedades do Primeiro Mundo e do Segundo Mundo - este último restando falido e aquele permanecendo como a condição presente, atual e contemporânea da evolução da Europa moderna. Note-se, por conseguinte, que, com o apagamento, o silenciamento e a invisiblização da tríade eurocentrismo-colonialismo-racismo e/como fascismo do processo de modernidade-modernização ocidental, desaparecem também seja os outros da modernidade como critério explicativo e como sujeito-práxis inseridos na modernização ocidental (e produzidos por ela), seja o próprio sentido do Terceiro Mundo, o qual, aliás, é exatamente uma produção caudatária da Guerra Fria, isto é, da expansão da modernidade-modernização ocidental sob a forma de mais um dualismo-maniquéísmo político-normativo-civilizacional próprio às potências econômico-políticoculturais contemporâneas em termos da díade capitalismo-comunismo. Na verdade, inclusive, a Guerra Fria, com esse dualismo antropológico-político-moral básico entre capitalismo e comunismo, é uma continuidade do colonialismo europeu calcado no racismo estrutural, agora obviamente reestilizado, o que mostra que o dualismo antropológico é uma constante e possui grande intensidade na dinamização do processo de constituição e de expansão da modernidade-modernização ocidental há quinhentos anos. Note-se, por conseguinte, que o dualismo antropológico europeu é mais, muito mais do que uma mera premissa científica ingênua, factual, neutra e objetiva para o estudo das sociedades primitivas ou arcaicas e, então, para a definição por antonomásia da própria Europa; ele é um princípio políticonormativo demarcado pelo eurocentrismo epistêmico e pela centralização e monopolização, por parte do pensamento euronorcêntrico, da capacidade discursiva e de ação prática relativamente à condição humana de um modo geral e no que se refere tanto à crítica da modernidade quanto ao enquadramento, à reflexividade, à interpretação e à condução de todos os outros da modernidade.

Duas conclusões emergem daqui. Primeira, de que sem o dualismo antropológico toda a autopressuposição da singularidade da Europa e da generalidade dos outros da Europa, com a separação, a endogenia e o purismo absolutos de um e de outro, bem como com a ideia consequente da modernidade como presente, atualidade e abertura ao futuro e dos outros da modernidade como passado antropológico, cai por terra. Segundo e como consequência, de que apenas através da afirmação do dualismo antropológico o discurso filosófico-sociológico-antropológico da modernidade-modernização ocidental pode sustentar que a crítica, a reflexividade, a mobilidade e a emancipação da modernidade e de todos os outros da modernidade pela própria modernidade somente podem ser feitas desde o paradigma normativo da modernidade, porque somente ele, enquanto perspectiva pós-tradicional, gera efetivamente desnaturalização, historicização e politização da sociedade-cultura-consciência, viabilizando, então, crítica, reflexividade, mobilidade e transformação ao longo do tempo - ao contrário do tradicionalismo em geral, do mito, que, naturalizados e despolitizados, consolidam o fundamentalismo, o dogmatismo, a imobilidade, a ausência de crítica, de reflexividade e de transformação. O dualismo antropológico separa, antagoniza, purifica e individualiza a Europa como singularidade e todos os outros da Europa como generalidade indiferenciada e fusionada; o dualismo antropológico transforma a Europa e os outros da Europa em dinâmicas basicamente endógenas, autorreferenciais e autossubsistentes, sem qualquer reciprocidade e mutualidade; e, finalmente, o dualismo antropológico deslegitima os outros da modernidade e apaga, invisibiliza e silencia a tríade eurocentrismo-colonialismo-racismo e/como fascismo enquanto eixo estruturante do processo de modernidade-modernização europeu - por isso, mais uma vez, essa tríade não aparece uma vez sequer nas teorias da modernidade europeias acima citadas como princípio constitutivo, dinâmica expansiva e consequência teórico-prática do processo de modernidade-modernização europeia. Ele simplesmente é externo à Europa, no máximo uma sua consequência acidental, não fundacional, não estruturante, ao ponto de não riscar sequer minimamente essa correlação, pressuposta pelo discurso filosóficosociológico-antropológico da modernidade-modernização ocidental, de Europa, racionalização e universalismo pós-tradicional, de Europa, autoconsciência, desnaturalização, historicização, politização, crítica, reflexividade, mobilidade e emancipação humanas. É por isso que o dualismo antropológico europeu leva à cegueira histórico-sociológica relativamente à compreensão e à definição do processo de 
modernidade-modernização ocidental, especialmente pela invisiblização, pelo silenciamento e pela negação do eurocentrismo-colonialismo-racismo e/como fascismo e pela endogenia, separação e autorreferencialidade absolutas da Europa em relação ao pré-moderno, bem como à romantização normativo-filosófica do racionalismo ocidental como o único princípios-lugar da crítica, da reflexividade, da mobilidade e da emancipação, com a consequente deslegitimação de todos os outros da modernidade europeia como passado antropológico, dogmatismo, fundamentalismo, contextualismo, particularismo, enquanto ausência de autoconsciência, crítica, reflexividade, mobilidade e transformação ao longo do tempo, ossificados, imobilizados e travados nesse mesmo passado antropológico.

Como dissemos, a descolonização africana, por meio da constituição de uma voz-práxis anticolonial, antifascista e antirracista, derruba com esse dualismo antropológico entre a Europamodernidade e todos os outros da Europa como pré-modernidade na medida em que utiliza a tríade eurocentrismo-colonialismo-racismo e/como fascismo para definir a constituição da modernidademodernização ocidental desde a correlação de um movimento expansivo universalista em termos de usurpação territorial, instrumentalização econômica, produção de menoridades político-culturais e realização de etnocídios-etnocídios práticos, bem como, a partir disso, sob a forma de uma regressão totalizante interna, sob a forma de fascismo-totalitarismo-racismo de europeus contra europeus: se, na expansão universalizante da Europa relativamente aos povos negros, indigenas e orientais, europeus instrumentalizaram, roubaram, violentaram e mataram não-europeus, desde a intersecção de racismo biológico e de filosofia da história etnocêntrica, na regressão totalizante dessa mesma Europa tivemos exatamente os regimes fascistas e totalitários calcados no racismo estrutural, que, explodindo no século XX, semearam a violência e a morte na Europa como um todo e, antes de tudo, no mundo como um todo - inclusive, saliente-se fortemente, com o combate do fascismo internamente à Europa e com a manutenção de colônias e do racismo estrutural na África e na Ásia; com a constituição da ONU e a afirmação da Declaração Universal dos Direitos Humanos por signatários (por exemplo, EUA, Inglaterra e França) que, concomitantemente, possuíam colônias na África e na Ásia e que ainda assumiam a segregação racial interna). Por meio da tríade eurocentrismo-colonialismo-racismo e/como fascismo, aparece-nos duas consequências fundacionais do processo de modernidade-modernização ocidental, a saber: de que os outros da modernidade são, na verdade, produções da própria Europa como menoridades político-culturais, como condições pré-modernas e, em muitos casos, antimodernas e antimodernizantes, as quais, concebidas desde o racismo biológico e a filosofia da história etnocêntrica, seriam reduzidos a instrumentalidade, mera animalidade, podendo ser explorados, usurpados, violentados e, quando necessário, simplesmente mortos; e de que esse dualismo antropológico entre modernidade e pré-modernidade, entre a Europa como singularidade e todos os outros da Europa como generalidade é uma consequência direta do dualismo-maniquésmo antropológico próprio ao regime colonial e, portanto, definidos em termos mais uma vez do racismo estrutural, da correlação entre branco como sujeito e índio-negro-oriental como objeto, ao mesmo tempo que de seu antagonismo e de sua contradição, com o que se criaria uma sociedade sem mediações demarcada pela produção e pela reprodução permanentes de minorias politico-culturais e, nesse sentido, pelo massacre cotidiano e intenso dos povos negros e indígenas sob a forma de etnocídio-genocídio planificado. Nesse sentido, a descolonização africana apontará para a destruição teórico-prática da tríade eurocentrismo-colonialismoracismo como o eixo estruturante para a derrubada dessa situação universalizada de periferização dos outros da modernidade por parte da Europa, o que significa e exige, em primeiro lugar, a desconstrução e a deslegitimação desse dualismo-maniqueísmo antropológico assumido pela cultura europeia relativamente a todos os outros da modernidade. Com isso, a voz-práxis negra-indígena como descolonização passa para primeiro plano seja em termos de reconstrução e de interpretação da história e dos fundamentos do processo de modernidade-modernização ocidental, agora imbricando centros e periferias, branco-índio-negro, Europa e todos os outros da Europa, modernidade e pré-modernidade nesse horizonte político-histórico constituído em termos de eurocentrismo-colonialismo-racismo e/como fascismo, seja no que se refere à constituição de um efetivo universalismo não-etnocêntrico e nãoegocêntrico com caráter anticolonial, antifascista, antitotalitário, antirracista e não-fundamentalista que parte exatamente da afirmação dos lugares de fala negros e indigenas e, nesse caso, da visibilização de suas experiência de marginalização, de exclusão e de violência vividas e sofridas em termos do processo de modernidade-modernização ocidental. Note-se, nesse caso, que o universalismo anticolonial, antifascista, antitotalitário, antirracista e não-fundamentalista emerge não por meio do sustento e da utilização do dualismo antropológico europeu, por meio da defesa de uma autorreferencialidade, de uma 
autossubsistência e de uma endogenia absolutas da Europa por si mesma e desde dentro de si mesma, mas exatamente em termos de visibilização do eurocentrismo-colonialismo-racismo e/como fascismo, com o que ter-se-ia concomitantemente uma crítica substantiva do processo de modernidademodernização ocidental e, então, uma práxis reparatória, corretiva e inclusiva que parte do contato entre Europa e os outros da Europa em termos de instrumentalização, usurpação e etnocídio-genocídio. Nesse caso, como estamos insistindo, é a voz-práxis negra e indígena como descolonização que permite a reflexividade, a crítica, a mobilidade e a emancipação da modernidade-modernização ocidental em relação ao seu dualismo antropológico, à sua cegueira histórico-sociológica e à sua romantização normativa do racionalismo ocidental. Com efeito, o dualismo antropológico, na medida em que sustenta a ilusão de um purismo, de uma separação e de uma endogenia absolutos da Europa como singularidade (na correlação de racionalização sociocultural e universalismo pós-tradicional) frente a todos os outros da modernidade como tradicionalismo em geral, como contextualismo-particularismo estrito e como fundamentalismo-dogmatismo político-moral-cultural, torna a Europa acrítica, irreflexiva, incapaz de conscientização e, com isso, imobiliza-a, trava-a, ossifica-a e a prende no passado antropológico, como dogmatismo, fundamentalismo e contextualismo-particularismo, de modo que ela se torna incapaz de reconhecer as alteridades enquanto alteridades, de posicionar-se e de relacionar-se de modo simétrico e horizontalizado com os outros de si e, com isso, de oferecer uma base normativa universalista capaz de sustentar uma crítica e uma transformação de si mesmas, uma crítica dos outros da modernidade e, então, impedindo-a de se autopressupor como guarda-chuva normativo da diversidade humana, como plataforma justificadora e sustentadora de uma noção cosmopolita de direitos humanos e abertura, planejamento e direcionamento ao futuro. O dualismo antropológico solidifica um ego absoluto que não vê nada além de si mesmo e que reduz todos os outros a si, interpretando-os como um espelho de si, ou seja, que é incapaz de maturidade, de autoconsciência e de juízo crítico, o que também significa que aquilo que a modernidade concebe relativamente aos outros da modernidade é pura e simplesmente aquilo que ela é, ou seja, menoridade político-cultural, violência simbólico-material e, assim, fundamentalismo, fanatismo e dogmatismo morais. É aqui que o papel educativo da voz-práxis negra e indígena como descolonização emerge com toda a pujança e esclarece o Esclarecimento acerca de seu dualismo antropológico, de sua cegueira histórico-sociológica e de sua romantização normativofilosófica do racionalismo ocidental, por meio da tríade eurocentrismo-colonialismo-racismo e/como fascismo.

\section{REFERÊNCIAS}

CÉSAIRE, Aimé. Discurso sobre o colonialismo. Lisboa: Livraria Sá da Costa Editora, 1978. DARWIN, Charles. A origem do homem e a seleção sexual. São Paulo: Hemus, 1974.

FANON, Frantz. Os condenados da terra. Rio de Janeiro: Paz e Terra, 1968.

FANON, Frantz. Pele negra, máscaras brancas. Salvador: Editora da UFBA, 2008.

HABERMAS, Jürgen. Teoria do agir comunicativo (Vol. I): racionalidade da ação e racionalização social. São Paulo: Martins Fontes, 2012a.

HABERMAS, Jürgen. Teoria do agir comunicativo (Vol. II): sobre a crítica da razão funcionalista. São Paulo: Martins Fontes, 2012b.

HABERMAS, Jürgen. O discurso filosófico da modernidade: doze lições. São Paulo: Martins Fontes, 2002a.

HABERMAS, Jürgen. A inclusão do outros: estudos de teoria política. São Paulo: Loyola, 2002b.

HONNETH, Axel. Luta por reconhecimento: a gramática moral dos conflitos sociais. São Paulo: Editora 34, 2003.

KRENAK, Ailton. Encontros. Rio de Janeiro: Azougue Editorial, 2015.

MBEMBE, Achille. Sair da grande noite: ensaio sobre a África descolonizada. Luanda: Edições Mulemba, 2014a.

MBEMBE, Achille. Crítica da razão negra. Lisboa: Antígona, 2014b.

MEMMI, Aimé. Retrato do colonizado precedido pelo retrato do colonizador. Rio de Janeiro: Civilização Brasileira, 1967.

QUIJANO, Anibal. “Colonialidad y Modernidad/Racionalidade”, Perú Indígena, vol. 13, nº 29, p. $11-20,1992$.

QUIJANO, Aníbal. "Colonialidade do poder, eurocentrismo e América Latina", p. 125-142. In: CLACSO (Org.). A colonialidade do saber: eurocentrismo e ciências sociais. Buenos 
Aires: CLACSO Editora, 2005.

SCHELER, Max. A diferença essencial entre o homem e o animal. Lisboa: Lusofia, 2008.

WEBER, Max. Ensayos de sociología de la religión (T. I). Madrid: Taurus, 1984.

WERÁ JECUPÉ, Kaká. Ore Awé Roiru'a Ma: todas as vezes que dissemos adeus. São Paulo: Peirópolis, 2002.

\section{Notas}

$1 \mathrm{E}$ Weber complementa logo adiante do mesmo texto: "Por que, nestes lugares, não ocorreram seja a evolução cientifica, seja o desenvolvimento da ciência, seja o desenvolvimento da arte e o do Estado, assim como o da economia, pelos caminhos da racionalização que são característicos do Ocidente? Pois é evidente que, em todos os casos mencionados, se trata de um 'racionalismo' de tipo especial da cultura ocidental" (WEBER, 1984, p. 20; o destaque é de Weber).

2 Trata-se do mesmo argumento de Axel Honneth, obviamente com outras palavras: "[...] necessidade de conceber o modelo de conflito até agora apresentado não mais apenas como um quadro explicativo do surgimento de lutas sociais, mas também como quadro interpretativo de um processo de formação. Somente a referência a uma lógica universal da ampliação das relações de reconhecimento permite uma ordenação sistemática do que, caso contrário, permaneceria um fenômeno incompreendido; pois as lutas e os conflitos históricos, sempre ímpares, só desvelam sua posição na evolução social quando se torna apreensível a função que eles desempenham para o estabelecimento de um progresso moral na dimensão do reconhecimento" (HONNETH, 2003, p. 265; os destaques são nossos). 